\title{
Post-Closure Evaluation of the Area 3 and Area 5 Radioactive Waste Management Sites at the Nevada National Security Site in Support of the Site-Wide Environmental Impact Statement
}

Prepared by

National Security Technologies, LLC

National Security Technologies Luc

Under Contract Number

DE-AC52-06NA25946

April 2011 


\title{
DISCLAIMER
}

Reference herein to any specific commercial product, process, or service by trade name, trademark, manufacturer, or otherwise does not necessarily constitute or imply its endorsement, recommendation, or favoring by the U.S. Government or any agency thereof or its contractors or subcontractors.

Available for sale to the public, in paper, from:

U.S. Department of Commerce

National Technical Information Service

5301 Shawnee Road

Alexandria, VA 22312

Phone: (800) 553-6847

Fax: (703) 605-6900

E-mail: orders@ntis.gov

Online Ordering: http://www.ntis.gov/help/ordermethods.aspx

Available electronically at http://www.osti.gov/bridge

Available for a processing fee to the U.S. Department of Energy and its contractors, in paper, from:

\author{
U.S. Department of Energy \\ Office of Scientific and Technical Information \\ P.O. Box 62 \\ Oak Ridge, TN 37831-0062 \\ Phone: (865) 576-8401 \\ Fax: (865) 576-5728 \\ E-mail: reports@adonis.osti.gov
}




\section{EXECUTIVE SUMMARY}

The post-closure performance of the Area 3 Radioactive Waste Management Site (RWMS) and Area 5 RWMS are evaluated for the Site-Wide Environmental Impact Statement using current performance assessment and composite analysis methods and models. Two alternatives with different future waste volumes and inventories are evaluated. The No Action Alternative evaluates the inventory disposed through fiscal year (FY) 2010 plus an additional 4.5E5 cubic meters $\left(\mathrm{m}^{3}\right)$ (1.59E7 cubic feet $\left[\mathrm{ft}^{3}\right]$ ) of waste disposed at the Area $5 \mathrm{RWMS}$. The Expanded Operations Alternative evaluates the FY 2010 inventory plus an additional $1.42 \mathrm{E} 6 \mathrm{~m}^{3}$ $\left(5.03 \mathrm{E} 7 \mathrm{ft}^{3}\right)$ of waste disposed at the Area $5 \mathrm{RWMS}$ and $4.93 \mathrm{E} 4 \mathrm{~m}^{3}\left(1.74 \mathrm{E} 6 \mathrm{ft}^{3}\right)$ disposed at the Area 3 RWMS.

Both the No Action and Expanded Operations Alternatives have a reasonable expectation of meeting all performance objectives of U.S. Department of Energy Order DOE O 435.1, "Radioactive Waste Management." No significant difference between the two alternatives was found because the waste concentrations are similar. The performance assessment model assesses radiological risk for residents at the RWMS boundary where risk is more closely related to waste concentration than total waste inventory. Results for the composite analysis also indicate that the dose constraint and dose limit can be met for both alternatives. 
This Page Intentionally Left Blank 


\section{Table of Contents}

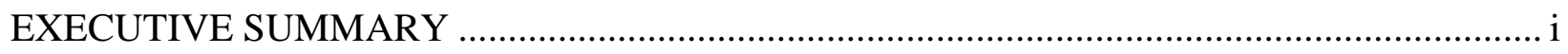

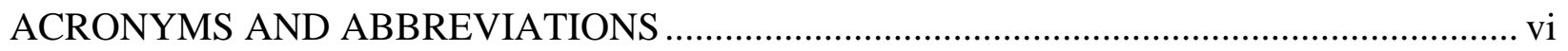

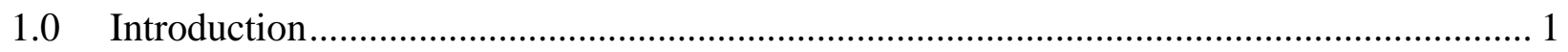

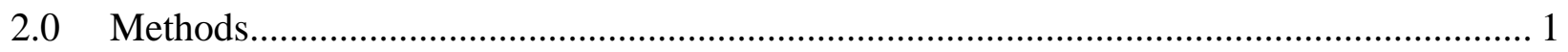

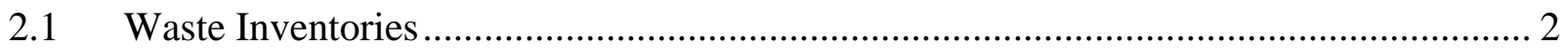

2.2 Performance Assessment and Composite Analysis ………………………………......... 3

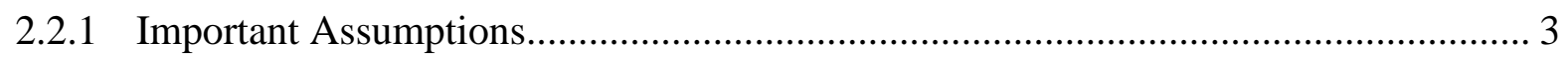

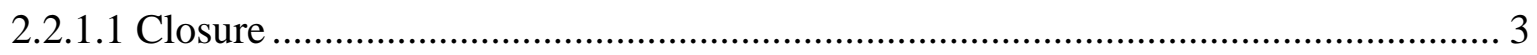

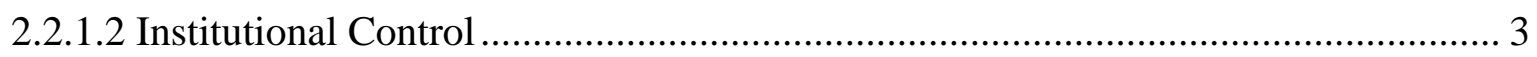

2.2.1.3 Source Term .............................................................................................. 3

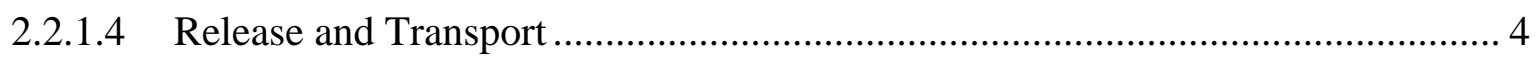

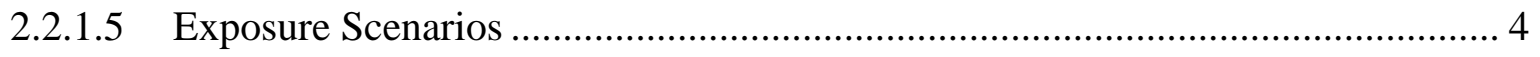

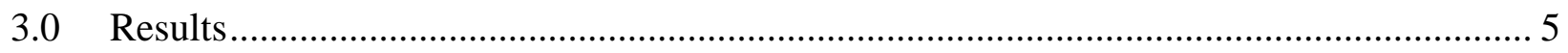

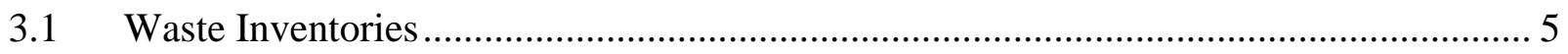

3.1.1 No Action Alternative ......................................................................................... 5

3.1.2 Expanded Operations Alternative........................................................................ 6

3.2 Performance Assessment Results ........................................................................... 7

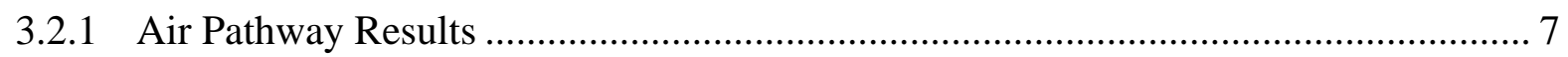

3.2.1.1 Air Pathway Parameter Uncertainty ................................................................. 9

3.2.1.2 Air Pathway Scenario Uncertainty ………………........................................... 11

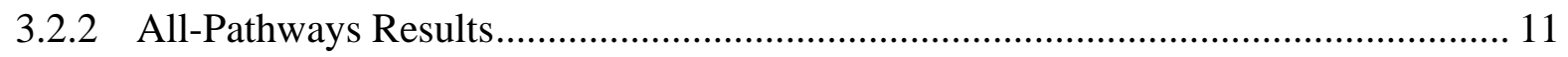

3.2.2.1 All-Pathways Parameter Uncertainty ………………………………………... 13

3.2.2.2 All-Pathways Scenario Uncertainty …………………………………………... 15

3.2.3 ${ }^{222}$ Rn Flux Density Results ....................................................................................... 15

3.2.3.1 ${ }^{222}$ Rn Flux Density Parameter Uncertainty …….................................................... 16

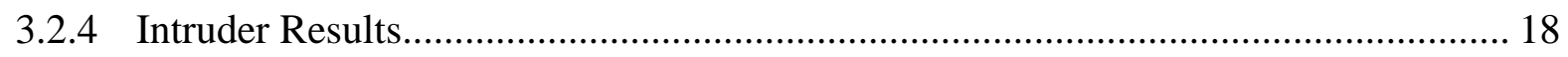

3.2.4.1 Intruder Scenario Uncertainty …………………........................................ 19

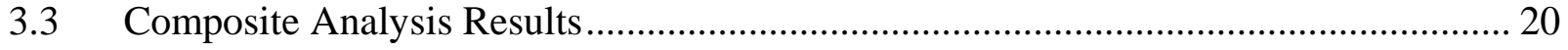

4.0 Conclusions .......................................................................................................... 22

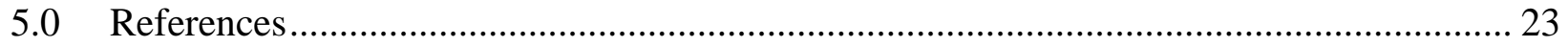

Appendix A.1 Waste Volumes and Inventories........................................................................ 25 


\section{List of Figures}

Figure 3-1. Cumulative volume and volume disposal rate for the Area 5 RWMS No Action

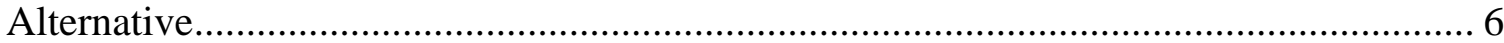

Figure 3-2. Cumulative volume and volume disposal rate for the Area 5 RWMS Expanded

Operations Alternative ............................................................................................ 6

Figure 3-3. Cumulative volume and volume disposal rate for the Area 3 RWMS Expanded Operations Alternative ............................................................................................... 7

Figure 3-4. Time history of the resident air pathway annual TED for the Area 5 RWMS Expanded Operations Alternative ......................................................................... 8

Figure 3-5. Time history of the resident farmer air pathway annual TED for the Area 3 RWMS

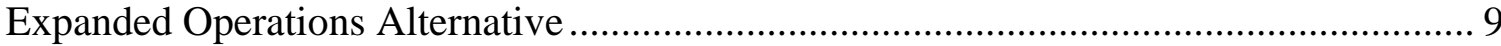

Figure 3-6. Histogram of non-zero values (left) and empirical cumulative distribution function (right) of the resident air pathway TED at 1,000 y for the Area 5 RWMS Expanded Operations Alternative ................................................................................... 10

Figure 3-7. Histogram of non-zero values (left) and empirical cumulative distribution function (right) of the resident farmer air pathway TED at 1,000 y for the Area 3 RWMS Expanded Operations Alternative.

Figure 3-8. Time history of the resident all-pathway annual TED for the Area 5 RWMS Expanded Operations Alternative .......................................................................... 12

Figure 3-9. Time history of the resident all-pathway annual TED for the Area 3 RWMS Expanded Operations Alternative ................................................................................ 13

Figure 3-10. Histogram of non-zero values (left) and empirical cumulative distribution function (right) of the resident all-pathways TED at 1,000 y for the Area 5 RWMS Expanded Operations Alternative

Figure 3-11. Histogram of non-zero values (left) and empirical cumulative distribution function (right) of the resident farmer all-pathways TED at $100 \mathrm{y}$ for the Area 3 RWMS Expanded Operations Alternative. Performance objective shown as blue vertical line. 14

Figure 3-12. Time history of the ${ }^{222} \mathrm{Rn}$ flux density for the Area 5 RWMS Expanded Operations

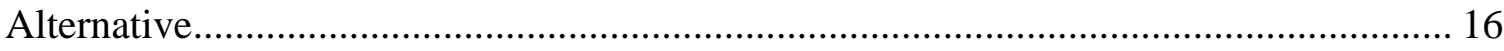

Figure 3-13. Histogram of non-zero values (left) and empirical cumulative distribution function (right) of the ${ }^{222}$ Rn flux density at 1,000 y for the Area 5 RWMS Expanded Operations Alternative. Performance objective shown as blue vertical line.

Figure 3-14. Histogram of non-zero values (left) and empirical cumulative distribution function (right) of the ${ }^{222} \mathrm{Rn}$ flux density at 1,000 y for the Area 3 RWMS Expanded Operations Alternative.

Figure 3-15. Time history of the acute construction scenario TED for the Area 5 RWMS SLB disposal units Expanded Operations Alternative

Figure 3-16. Time history of the composite analysis TED for the Area 5 RWMS Expanded Operations Alternative 


\section{List of Tables}

Table 3-1. Maximum air pathway annual TED results for the No Action and Expanded

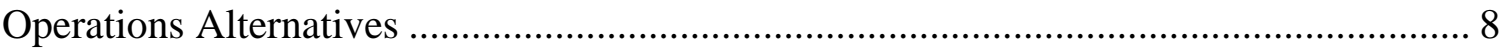

Table 3-2. Maximum air pathway TED results for alternative scenarios. ................................ 11

Table 3-3. Maximum all-pathway annual TED results for the No Action and Expanded Operations Alternatives. ................................................................................................ 12

Table 3-4. Maximum all-pathway annual TED results for alternative scenarios...................... 15

Table 3-5. Maximum ${ }^{222}$ Rn flux density results for the No Action and Expanded Operations

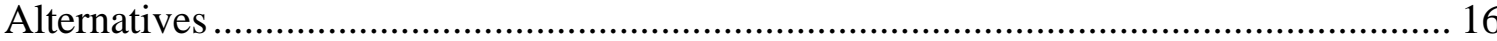

Table 3-6. Maximum acute intruder scenario results for the No Action and Expanded Operations Alternatives at the Area 5 RWMS SLB disposal units ................................... 18

Table 3-7. Maximum chronic intruder results weighted with the probability of intrusion for the No Action and Expanded Operations Alternatives at the Area 3 and Area 5 RWMSs 20

Table 3-8. Maximum composite analysis results for the No Action and Expanded Operations

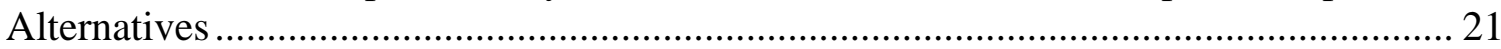

Table A1-1. Estimate of the future inventory for the No Action and Expanded Operations Alternatives. Estimates are calculated from 500 LHS realizations and decayed to October 1, 2028, for the Area 5 RWMS and October 1, 2025, for the Area 3 RWMS.................. 25 


\section{ACRONYMS AND ABBREVIATIONS}

\begin{tabular}{|c|c|}
\hline ALARA & as low as reasonably achievable \\
\hline $\mathrm{BN}$ & Bechtel Nevada \\
\hline $\mathrm{Bq}$ & becquerel \\
\hline $\mathrm{Bq} \mathrm{m}^{-2} \mathrm{~s}^{-1}$ & becquerel per square meter per second \\
\hline CA & composite analysis \\
\hline $\mathrm{DOE}$ & U.S. Department of Energy \\
\hline ecdf & empirical cumulative distribution function \\
\hline $\mathrm{ft}$ & foot (feet) \\
\hline $\mathrm{ft}^{3}$ & cubic meter(s) \\
\hline FY & fiscal year \\
\hline GCD & greater confinement disposal \\
\hline GM & geometric mean \\
\hline GSD & geometric standard deviation \\
\hline${ }^{3} \mathrm{H}$ & tritium \\
\hline LHS & Latin hypercube sampling \\
\hline $\mathrm{m}$ & meter(s) \\
\hline $\mathrm{m}^{3}$ & cubic meter(s) \\
\hline $\mathrm{mSv}$ & milliseivert \\
\hline NNSS & Nevada National Security Site \\
\hline NSTec & National Security Technologies, LLC \\
\hline $\mathrm{PA}$ & performance assessment \\
\hline${ }^{210} \mathrm{~Pb}$ & lead-210 \\
\hline${ }^{239} \mathrm{Pu}$ & plutonium-239 \\
\hline${ }^{226} \mathrm{Ra}$ & radium-226 \\
\hline RaDU & Radium Disposal Unit \\
\hline${ }^{222} \mathrm{Rn}$ & radon-222 \\
\hline RWMS & Radioactive Waste Management Site \\
\hline SLB & shallow land burial \\
\hline SWEIS & Site-Wide Environmental Impact Statement \\
\hline TED & total effective dose \\
\hline${ }^{229} \mathrm{Th}$ & thorium-229 \\
\hline TRU & transuranic \\
\hline${ }^{238} \mathrm{U}$ & uranium-238 \\
\hline & year(s) \\
\hline
\end{tabular}




\subsection{Introduction}

This report summarizes the methods and results of a post-closure evaluation of the Area 3 and Area 5 Radioactive Waste Management Sites (RWMSs) at the Nevada National Security Site (NNSS) performed in support of the Site-Wide Environmental Impact Statement (SWEIS). The long-term performance of the Area 3 and Area 5 RWMSs are evaluated under two alternatives with different waste volumes and inventories. The No Action Alternative evaluates the inventories disposed through fiscal year (FY) 2010 plus an additional 4.5E5 cubic meters $\left(\mathrm{m}^{3}\right)$ (1.59E7 cubic feet $\left[\mathrm{ft}^{3}\right]$ ) of waste disposed at the Area 5 RWMS. The Expanded Operations Alternative evaluates the FY 2010 inventory plus an additional $1.42 \mathrm{E} 6 \mathrm{~m}^{3}\left(5.03 \mathrm{E} 7 \mathrm{ft}^{3}\right)$ of waste disposed at the Area 5 RWMS and 4.93E4 $\mathrm{m}^{3}\left(1.74 \mathrm{E} 6 \mathrm{ft}^{3}\right)$ disposed at the Area $3 \mathrm{RWMS}$. The inventory, performance assessment (PA), and composite analysis (CA) models make no distinction between low-level and mixed wastes. Only hazards posed by radiological constituents are considered.

\subsection{Methods}

The post-closure evaluation uses the data and methods described in the Area 3 and Area 5 RWMS PA and CA documents (Shott et al., 1998; 2001; Bechtel Nevada [BN], 2001; 2006) to estimate PA and CA results for the No Action and Expanded Operations Alternatives. A PA is an analysis of a radioactive waste disposal facility conducted to demonstrate there is a reasonable expectation that performance objectives established for the long-term protection of the public and the environment in U.S. Department of Energy (DOE) Order DOE O 435.1, "Radioactive Waste Management” (DOE, 2001) will not be exceeded following closure of the facility. The DOE O 435.1 performance objectives apply to wastes disposed after September 26, 1988. A CA is an analysis that accounts for all sources of radioactive material that may contribute to the long-term dose projected to a hypothetical member of the public from an active or planned low-level waste disposal facility.

Incremental changes occurring since the last PA or CA are documented in annual summaries submitted to DOE (National Security Technologies, LLC [NSTec], 2008; 2009; 2010; 2011). Important changes to the Area 5 RWMS PA and CA models occurring since the last update (BN, 2001; 2006) include:

- Waste inventories and disposal unit configurations are updated through the end of FY 2010.

- A period of passive institutional control based on site knowledge follows the end of active institutional control. The length of passive controls is sampled from a probability density function based on elicitation of a panel of subject matter experts (Black et al., 2001).

- Termite burrowing has been removed from the model based on field studies that failed to identify significant soil movement by termite species.

- A residential exposure scenario has been added to the model.

- Drilling and construction acute intrusion scenarios have been added to the model. 
- The closure cover thickness over the shallow land burial (SLB) disposal units has been decreased from 4.0 meters $(\mathrm{m})$ (13 feet [ft]) to $2.5 \mathrm{~m}(8.2 \mathrm{ft})$ based on a cost-benefit optimization (Shott and Yucel, 2009).

- The source for dose conversion factors has changed from Federal Guidance Report 11 (Eckerman and Ryman, 1993) and 12 (Eckerman et al., 1998) to the Federal Guidance Report 13 supplemental compact disk (U.S. Environmental Protection Agency, 1999).

Important changes to the Area 3 RWMS PA and CA models occurring since the last PA/CA document (Shott et al., 2001) include:

- Waste inventories and disposal unit configurations are updated through the end of FY 2010.

- A probabilistic period of active and passive institutional control based on elicitation of a panel of subject matter experts (Black et al., 2001) has been added to the model.

- Biointrusion models and parameters have been updated based on Area 3 field studies.

- The member of public exposure scenarios are now a transient occupancy and resident farmer scenario.

Additional changes required for the post-closure evaluation are noted below.

\subsection{Waste Inventories}

The closure inventories for the two alternatives are the sum of actual inventories disposed though FY 2010 and estimated future inventories. The inventory disposed through FY 2010 is reported in NSTec (2011).

The future inventories for the two alternatives were estimated probabilistically with the Area 3 Inventory Model (version 2.016) and Area 5 Inventory Model (version 2.107). The algorithm for estimating future inventory is:

1. Randomly select a waste volume for the FY. The annual waste volume is normally distributed with mean equal to the alternative's disposal rate and standard deviation based on the observed differences between generator estimates of future waste volume and actual disposals.

2. For each radionuclide, randomly sample an activity concentration for the FY. The distribution of radionuclide concentration is a cumulative distribution of annual concentrations from previous FYs.

3. Calculate the inventory as the product of volume and activity concentration.

4. Repeat steps 1 through 4 for each future FY, including the process of radioactive decay and ingrowth.

5. Generate 500 realizations of Steps 1 through 4.

The algorithm above produces 500 realizations of inventory, which are fit to lognormal distributions. The mean annual waste volume is derived from the two alternatives assuming an equal volume in every future FY. The No Action Alternative assumes a mean waste disposal rate 
in the Area 5 RWMS SLB disposal units of 2.5E4 cubic meters per year $\left(\mathrm{m}^{3} \mathrm{y}^{-1}\right)$ (8.83E5 cubic feet per year $\left[\mathrm{ft}^{3} \mathrm{y}^{-1}\right]$ ) from FY 2011 through FY 2028. The Expanded Operations Alternative assumes a mean waste disposal rate of 7.91E4 $\mathrm{m}^{3} \mathrm{y}^{-1}\left(2.79 \mathrm{E} 6 \mathrm{ft}^{3} \mathrm{y}^{-1}\right)$ in the Area 5 RWMS SLB disposal units from FY 2011 through FY 2028 and a mean disposal rate of $3.29 \mathrm{E} 3 \mathrm{~m}^{3} \mathrm{y}^{-1}$ (1.16E5 $\mathrm{ft}^{3} \mathrm{y}^{-1}$ ) in U-3ah/at at the Area 3 RWMS from FY 2011 through FY 2025.

\subsection{Performance Assessment and Composite Analysis}

The current baseline PA and CA models, A3 RWMS v2.0 and A5 RWMS v4.110, were used for the post-closure evaluation with modifications for the future waste volumes and inventories. The Area 3 RWMS v2.0 model was used with disposal unit subsidence disabled.

\subsubsection{Important Assumptions}

\subsubsection{Closure}

The Area 3 RWMS is assumed to close on October 1, 2025. Each Area 3 RWMS disposal unit is assumed to be closed with a $3 \mathrm{~m}(9.8 \mathrm{ft})$ monolithic evapotranspirative cover. The Area 5 RWMS is assumed to close on October 1, 2028. The Area 5 RWMS SLB disposal units are assumed to be closed with a $2.5 \mathrm{~m}(8.2 \mathrm{ft})$ monolithic evapotranspirative cover.

\subsubsection{Institutional Control}

A probabilistic period of active institutional control is assumed based on an elicitation of a panel of subject matter experts (Black et al., 2001). Active institutional control is followed by a period of passive institutional control based on site knowledge. The total period of institutional control has a median length of 393 years (y). The probability that institutional controls will persist 100 and 1,000 y is 97 and 11 percent, respectively. Institutional controls are assumed to maintain doses at negligible levels. Exposures are not quantitatively evaluated until institutional controls end.

The NNSS's Institutional Control Policy (U.S. Department of Energy, National Nuclear Security Administration Nevada Site Office, 2007) to implement land-use restrictions for 1,000 y for Underground Test Areas is assumed to eliminate the possibility of chronic intrusion scenarios. Once institutional controls fail, acute or short-term exposure of intruders is assumed to be possible.

\subsubsection{Source Term}

The future waste inventories are summarized in Appendix A.1. Waste concentration is an average concentration, calculated by dividing the waste inventory by the disposal unit volume. Under the No Action Alternative, the Area 3 RWMS is assumed to receive no future waste.

Waste is assumed to be available for transport at closure. Waste containers and waste forms do not delay release. Waste is assumed to have alluvium-like properties. 


\subsubsection{Release and Transport}

Infiltrating precipitation is assumed to percolate to a depth of $2 \mathrm{~m}(6.6 \mathrm{ft})$ or less and then be returned to the atmosphere by evapotranspiration. Multiple lines of evidence suggest recharge of the uppermost aquifer through the valley fill alluvium ceased at the end of the last pluvial period more than 10,000 y ago. Contamination of the uppermost aquifer is assumed to be unlikely over the next $1,000 \mathrm{y}$.

Radionuclides are assumed to be released upwards to the land surface. Processes included in the model are:

- Upward liquid advection driven by large negative water potential in the near surface, maintained by high evapotranspiration.

- Gaseous and liquid diffusion driven by concentration gradients.

- Liquid phase transport is subject to linear adsorption on the solid phase and solubility limits.

- Plant uptake and translocation to aboveground tissue followed by senescence and transfer to the surface soil.

- Transfer of contaminated soil and waste to surface soil by animal burrowing. Soil is mixed downward by burrow collapse and infilling.

- Soil particulates are resuspended to the atmosphere. Resuspended soil and gases are advected off site.

The concentration of radionuclides released to surface soil is averaged over the area of the disposal units. The concentration of radionuclides in surface soil is linearly proportional to the concentration of waste. Soil at the $100 \mathrm{~m}$ (330 ft) site boundary is assumed to have the same concentration as disposal unit surface soil.

\subsubsection{Exposure Scenarios}

The member of public is assumed to be an average adult at the $100 \mathrm{~m}$ (330 ft) site boundary, engaged in activities and habits typical for the region. A residential exposure scenario is assumed for the Area 5 RWMS. The resident is assumed to live at the RWMS boundary and work 40 hours per week at a remote location. The resident consumes no contaminated agricultural products or drinking water.

A resident farmer exposure scenario is assumed for the Area 3 RWMS. Results for the resident scenario are not currently available for the Area 3 RWMS. The resident farmer resides at the

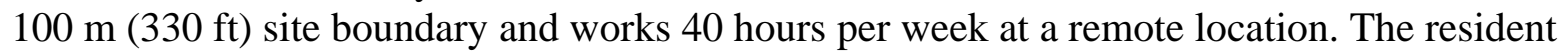
farmer is engaged in limited non-commercial agricultural activities in his spare time. The resident farmer consumes limited amounts of agricultural products produced on site. Agricultural production is limited by the infertile soil and limited contaminated area at the site.

Intrusion may occur by drilling or excavation of a basement for a residence. Two acute intruder scenarios are evaluated: a drilling scenario and a construction scenario. The drilling scenario assumes a drill crew is exposed to contaminated drill cuttings while drilling a water well through 
a disposal unit. The construction scenario assumes that construction workers are exposed to excavated waste while constructing a house with a basement on the disposal site. Acute intruder scenario results are available for the Area 5 RWMS only. Results are reported for the SLB disposal units, as these are the units assumed to receive future waste.

Exposure scenarios are evaluated for a period of 1,000 y after closure.

\subsection{Results}

\subsection{Waste Inventories}

The inventory used in the post-closure evaluation consists of a disposed inventory and an estimate of future inventory. The disposed inventory is the inventory disposed through FY 2010 as described in NSTec (2011). The Area 5 RWMS disposed inventory includes low-level, mixed, and transuranic (TRU) wastes. PA simulations are limited to the post-1988 waste inventory.

For the Area 5 RWMS the disposed inventory consists of four inventories corresponding to groups of disposal units with similar depths of burial. The four groups are the SLB units, the Pit 6 radium disposal unit (RaDU), the Pit $13 \mathrm{RaDU}$, and the greater confinement disposal (GCD) boreholes. The future inventory disposed under the No Action and Expanded Operations Alternatives are assumed to be part of the SLB disposal units.

The Area 3 RWMS disposed inventory includes inventories for three individual disposal units: U-3ax/bl, U-3ah/at, and U-3bh. The Area 3 RWMS inventory includes low-level and mixed wastes. Future waste is assumed to be disposed in U-3ah/at.

\subsubsection{No Action Alternative}

Under the No Action Alternative, the Area 5 RWMS SLB waste volume approximately doubles, increasing constantly from $6.1 \mathrm{E} 5 \mathrm{~m}^{3}\left(2.1 \mathrm{E} 7 \mathrm{ft}^{3}\right)$ in FY 2010 to $1.2 \mathrm{E} 6 \mathrm{~m}^{3}\left(4.2 \mathrm{E} 7 \mathrm{ft}^{3}\right)$ at the end of FY 2028 (Figure 3-1). The total inventory of long-lived nuclides, which is predominantly tritium $\left({ }^{3} \mathrm{H}\right)$, remains approximately constant as the ${ }^{3} \mathrm{H}$ disposal rates and the rate of loss by radioactive decay are similar. See Appendix A.1 for future inventories. 


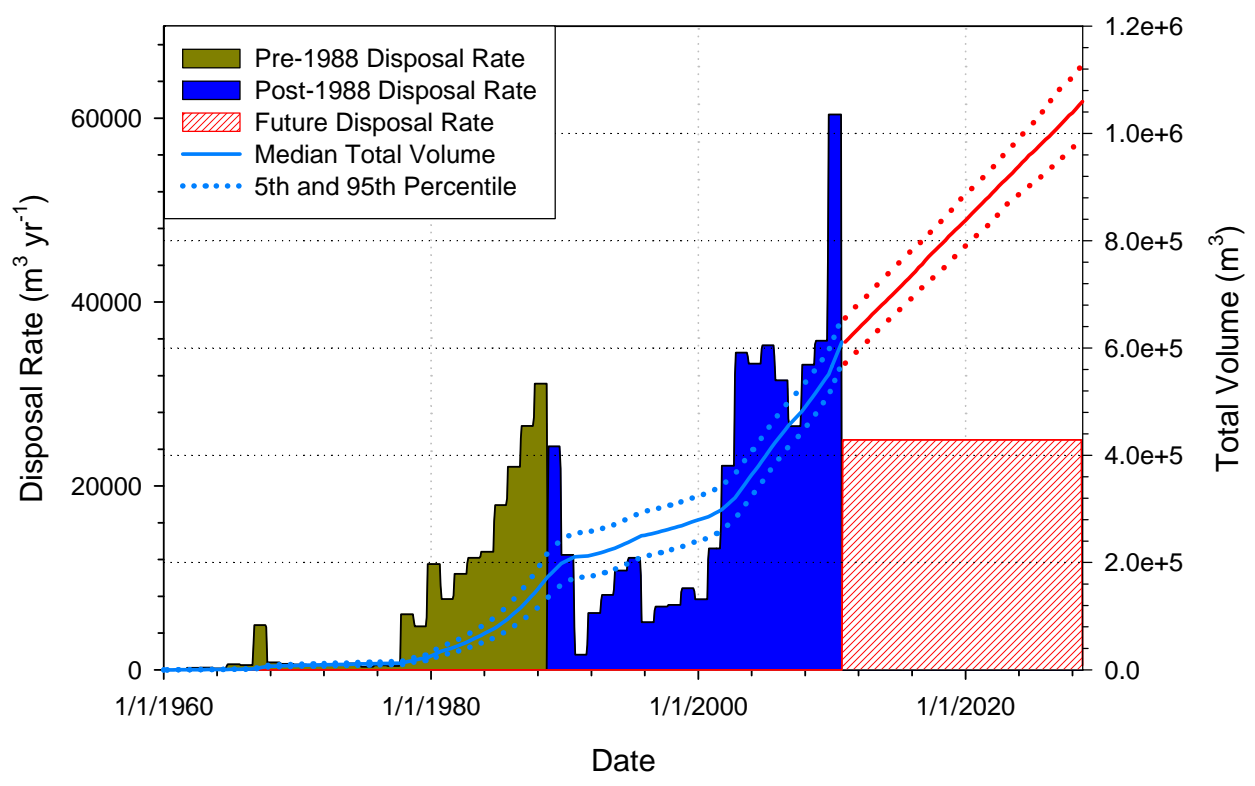

Figure 3-1. Cumulative volume and volume disposal rate for the Area 5 RWMS No Action Alternative

\subsubsection{Expanded Operations Alternative}

The Area 5 RWMS Expanded Operations Alternative assumes waste volume increases approximately three times from $6.1 \mathrm{E} 5 \mathrm{~m}^{3}\left(2.1 \mathrm{E} 7 \mathrm{ft}^{3}\right)$ in FY 2010 to $2.0 \mathrm{E} 6 \mathrm{~m}^{3}\left(7.1 \mathrm{E} 7 \mathrm{ft}^{3}\right)$ at the end of FY 2028 (Figure 3-2). The total long-lived radionuclide inventory approximately doubles.

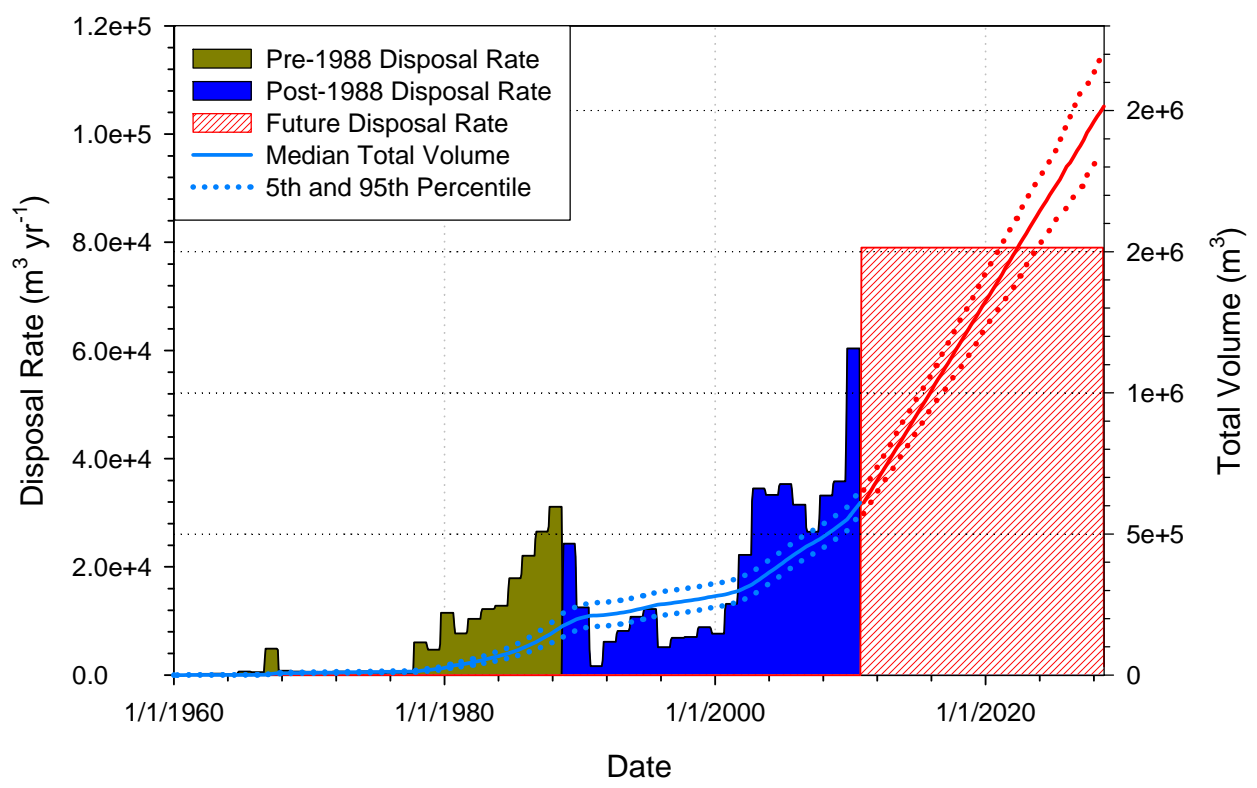

Figure 3-2. Cumulative volume and volume disposal rate for the Area 5 RWMS Expanded Operations Alternative 
The Area 3 RWMS was placed in inactive status in July of 2006. At that time it had received $5.7 \mathrm{E} 5 \mathrm{~m}^{3}\left(2.0 \mathrm{E} 7 \mathrm{ft}^{3}\right)$ of waste. Under the Expanded Operations Alternative, disposal begins in FY 2011 and waste volume increases moderately to $6.7 \mathrm{E} 5 \mathrm{~m}^{3}\left(2.4 \mathrm{E} 7 \mathrm{ft}^{3}\right)$ by closure in FY 2025 (Figure 3-3). The total long-lived nuclide inventory decreases rapidly during the extended operations as radioactive decay of disposed waste exceeds the future disposal rate.

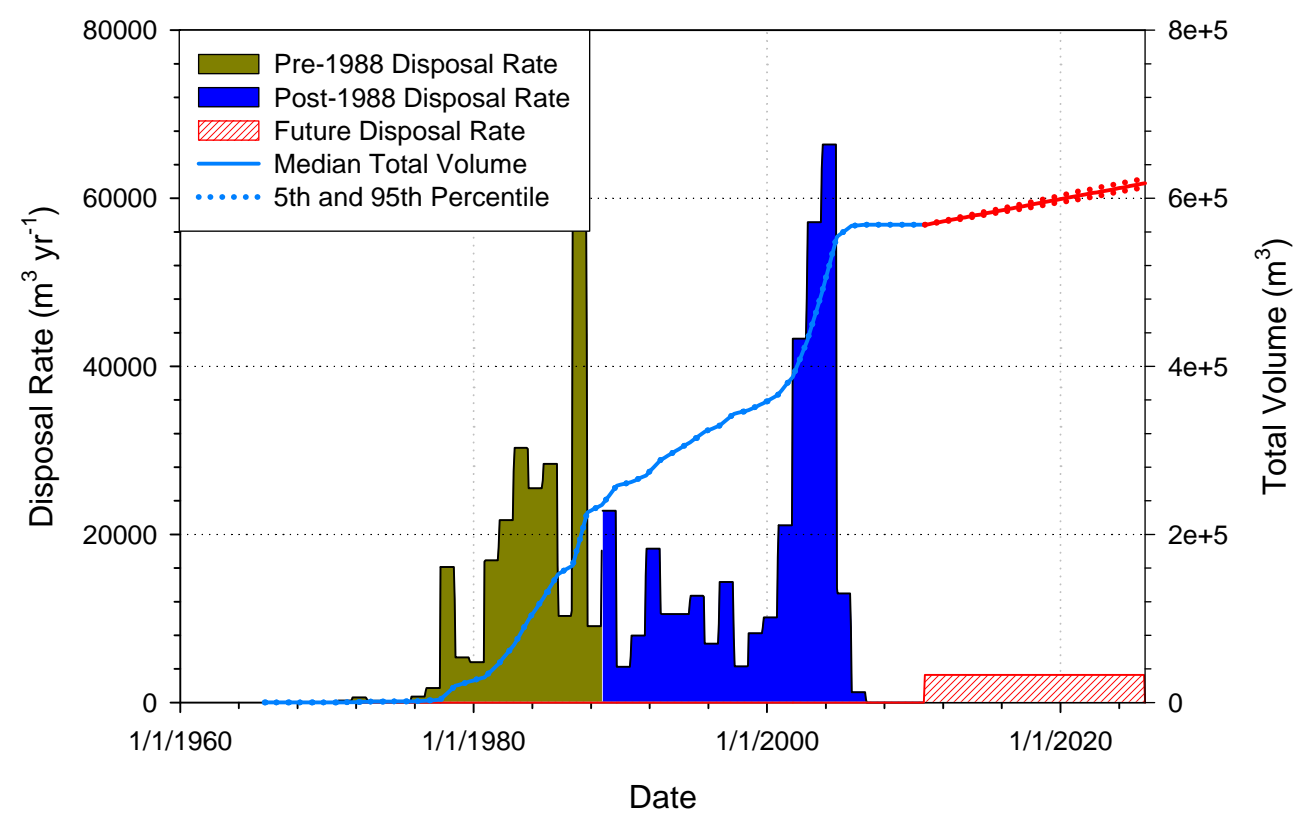

Figure 3-3. Cumulative volume and volume disposal rate for the Area 3 RWMS Expanded Operations Alternative

\subsection{Performance Assessment Results}

\subsubsection{Air Pathway Results}

Compliance with the 0.1 millisievert ( $\mathrm{mSv}$ ) in a year air pathway performance objective is assessed for the resident scenario for the Area 5 RWMS. Compliance at the Area 3 RWMS is assessed for the resident farmer scenario.

The mean and $95^{\text {th }}$ percentile air pathway annual total effective doses (TEDs) are less than the performance objective for the No Action and Expanded Operations Alternatives (Table 3-1). Even the $95^{\text {th }}$ percentile is a small fraction of the performance objective. The No Action and Expanded Operations Alternative produce similar TEDs at the Area 5 RWMS because the TED is proportional to the waste concentration, which is similar for both alternatives. Risk to a resident living in close proximity to the RWMSs is more reasonably related to waste concentration than total inventory. 
Table 3-1. Maximum air pathway annual TED results for the No Action and Expanded Operations Alternatives

\begin{tabular}{|c|c|c|c|c|c|}
\hline RWMS & Scenario & Alternative & $\begin{array}{c}\text { Mean TED } \\
(\mathrm{mSv})\end{array}$ & $\begin{array}{c}95^{\text {th }} \text { Percentile } \\
(\mathrm{mSv})\end{array}$ & $\begin{array}{c}\text { Time of } \\
\text { Maximum (y) }\end{array}$ \\
\hline \multirow{2}{*}{ Area 5 } & \multirow{2}{*}{ Resident } & No Action & $1.4 \mathrm{E}-4$ & $5.2 \mathrm{E}-4$ & 1,000 \\
\cline { 3 - 6 } & Expanded Operations & $1.3 \mathrm{E}-4$ & $4.8 \mathrm{E}-4$ & 1,000 \\
\hline Area 3 & $\begin{array}{c}\text { Resident } \\
\text { Farmer }\end{array}$ & Expanded Operations & $5.4 \mathrm{E}-6$ & $1.6 \mathrm{E}-5$ & 1,000 \\
\hline
\end{tabular}

The maximum mean resident TED at the Area 5 RWMS occurs at 1,000 y for the Expanded Operations Alternative (Figure 3-4). Similar results are observed for the No Action Alternative. The TED at 1,000 y is contributed predominantly by inhalation of thorium-229 $\left({ }^{229} \mathrm{Th}\right)$ and uranium-238 $\left({ }^{238} \mathrm{U}\right)$. The $5^{\text {th }}$ percentile TED is zero over $1,000 \mathrm{y}$ due to a greater than 5 percent probability that institutional controls will remain effective throughout the compliance period.

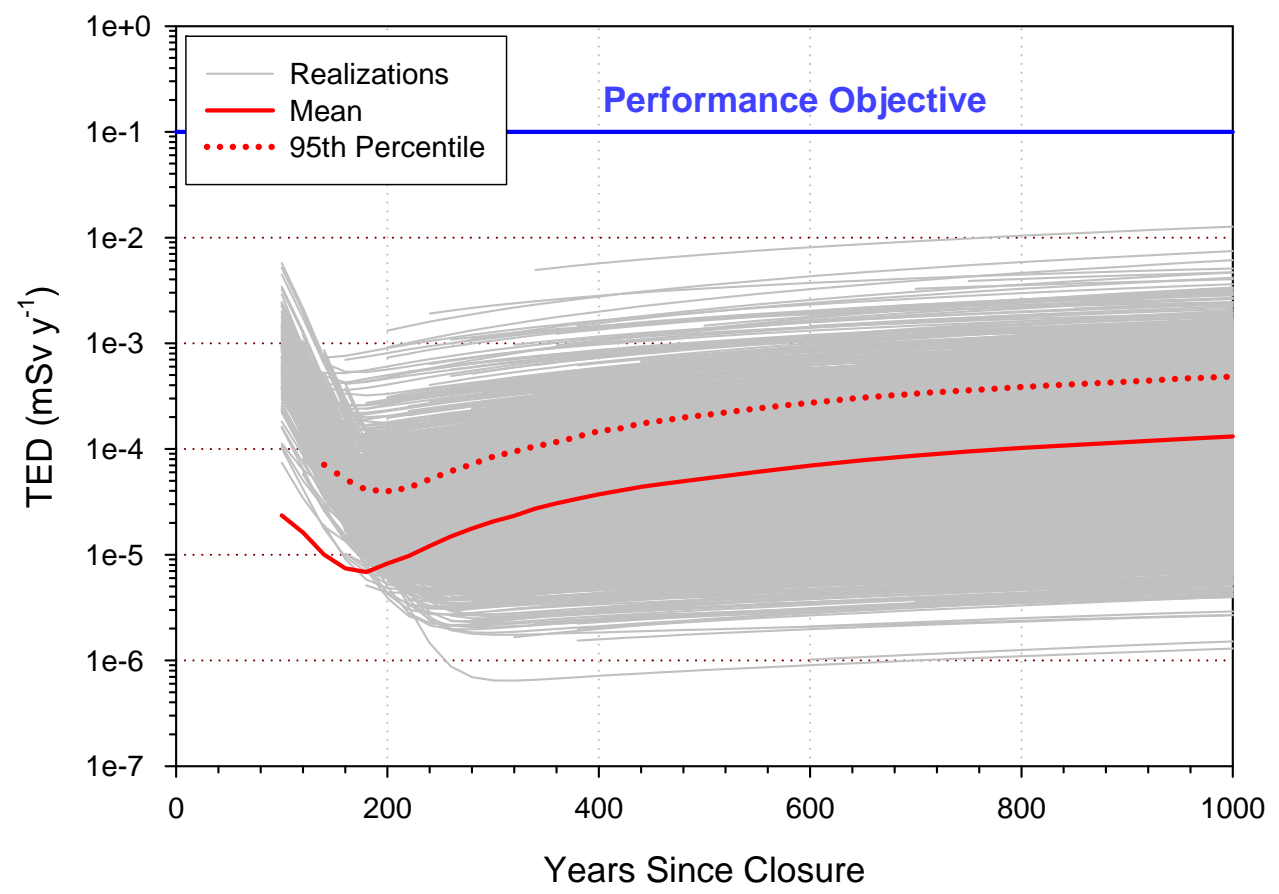

Figure 3-4. Time history of the resident air pathway annual TED for the Area 5 RWMS Expanded Operations Alternative

The maximum mean resident farmer TED at the Area 3 RWMS occurs at 1,000 y for the Expanded Operations Alternative (Figure 3-5). The Area 3 RWMS air pathway TED at 1,000 y is contributed predominantly by inhalation of lead-210 $\left({ }^{210} \mathrm{~Pb}\right)$. 


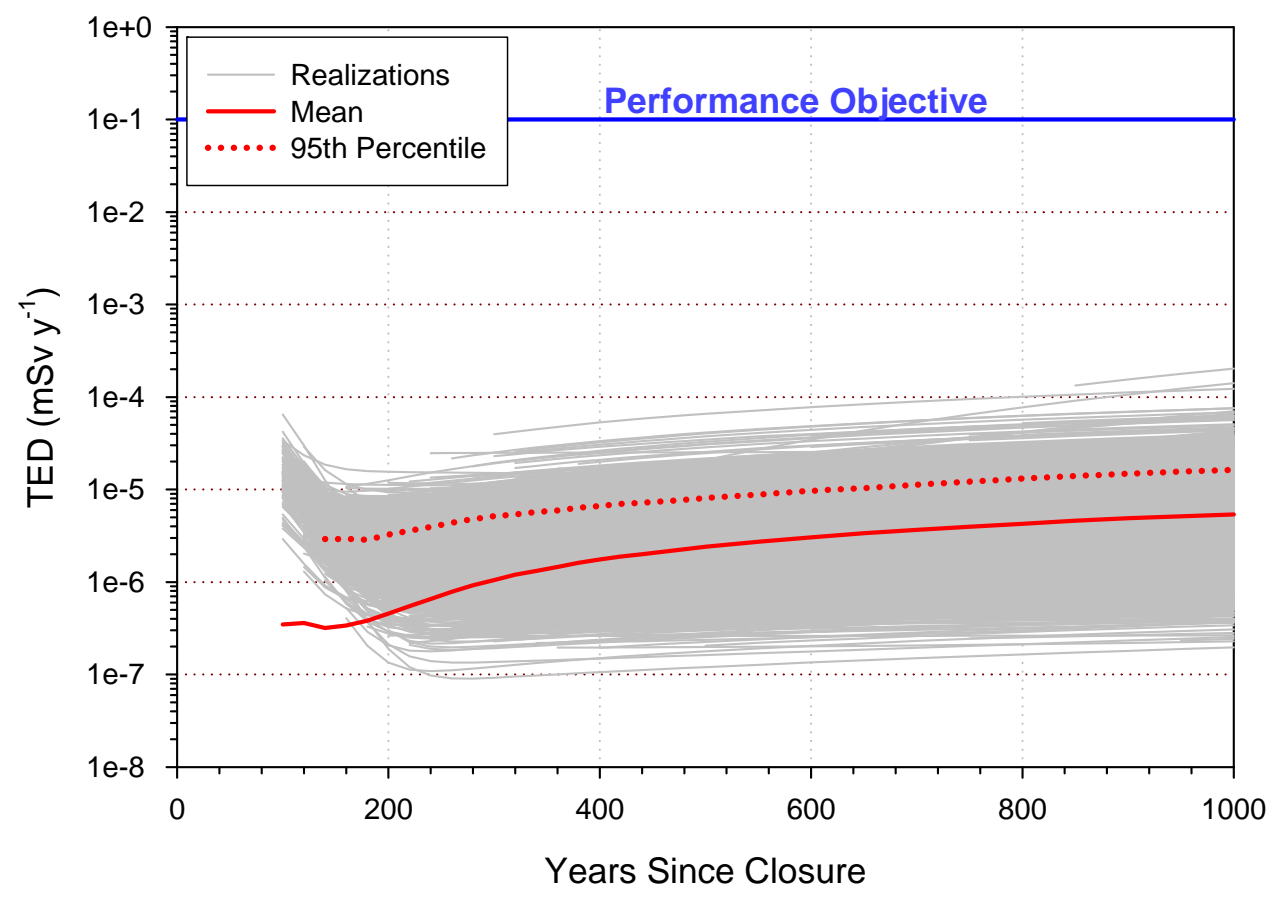

Figure 3-5. Time history of the resident farmer air pathway annual TED for the Area 3 RWMS Expanded Operations Alternative

\subsubsection{Air Pathway Parameter Uncertainty}

Parameter uncertainty is propagated through the PA model by Monte Carlo simulation. All results are based on 5,000 Latin hypercube sampling (LHS) realizations. Air pathway parameter uncertainty is assessed for the Expanded Operations Alternative at 1,000 y.

The Area 5 RWMS resident TED at 1,000 y is skewed to the right and relatively symmetric when log transformed (Figure 3-6). The empirical cumulative distribution function (ecdf) indicates that there is a very low probability of exceeding the performance objective, as no realization exceeds the performance objective. The ecdf indicates that approximately 11 percent of the realizations are zero at 1,000 y. The zero TED values occur for realizations where institutional controls remain effective throughout the 1,000-y compliance period.

The Area 3 RWMS resident farmer TED at 1,000 y is skewed to the right and relatively symmetric when log transformed (Figure 3-7). The ecdf indicates that there is a very low probability of exceeding the performance objective. No realizations were observed to exceed the limit. The ecdf indicates that approximately 11 percent of the realizations are zero at 1,000 y. The zero values are due to the persistence of institutional control throughout the compliance period. 

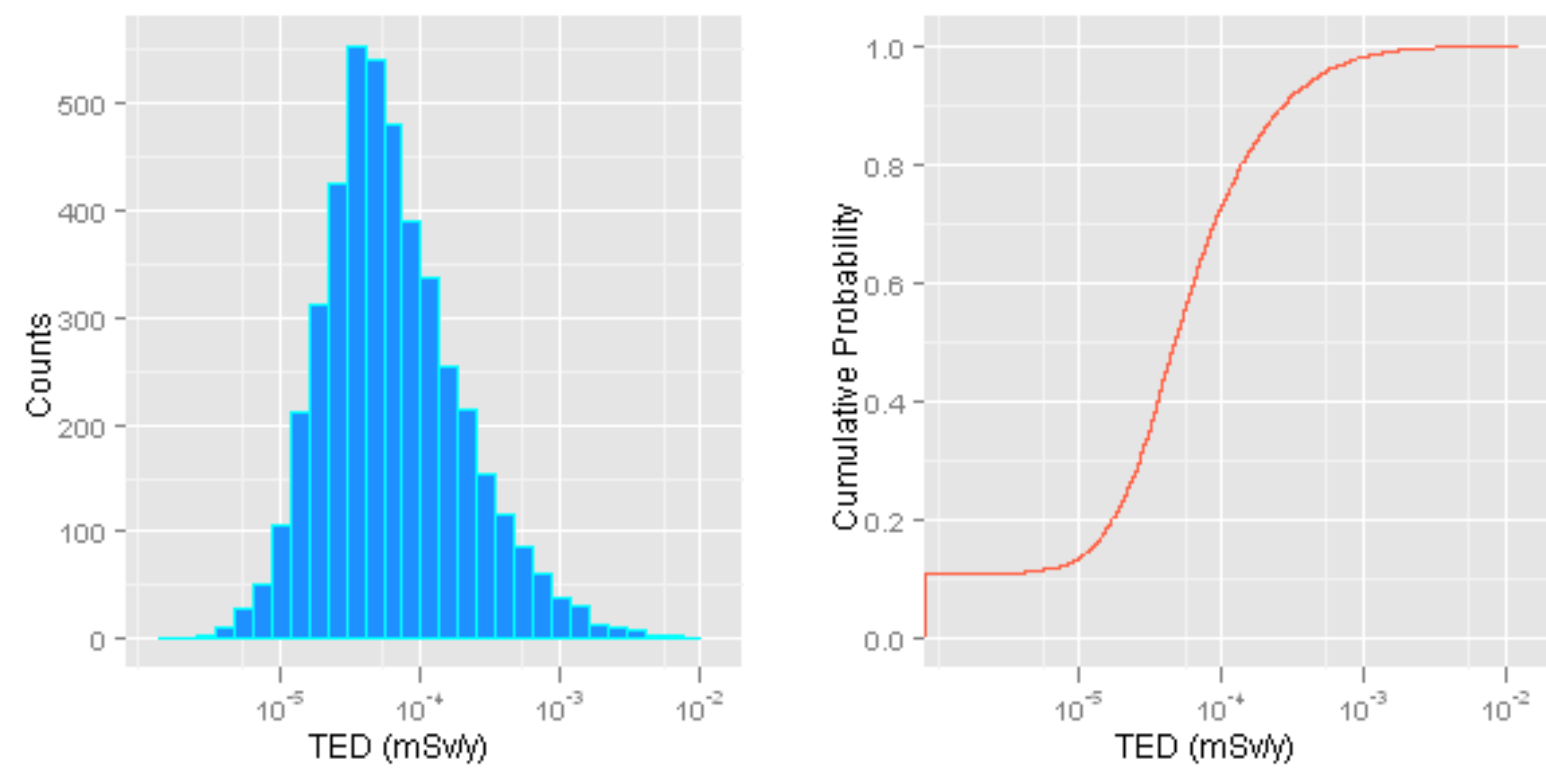

Figure 3-6. Histogram of non-zero values (left) and empirical cumulative distribution function (right) of the resident air pathway TED at 1,000 y for the Area 5 RWMS Expanded Operations Alternative
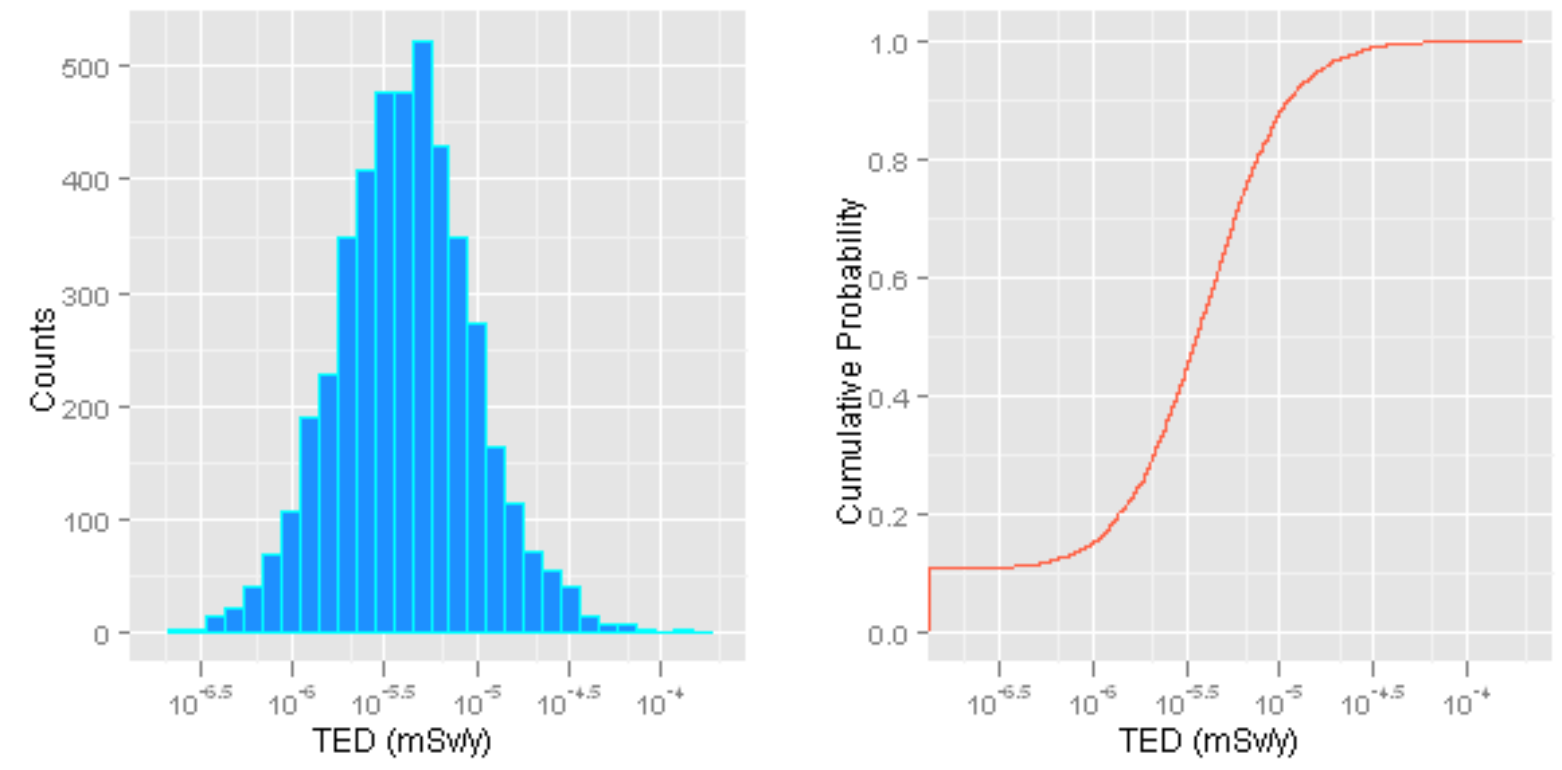

Figure 3-7. Histogram of non-zero values (left) and empirical cumulative distribution function (right) of the resident farmer air pathway TED at 1,000 y for the Area 3 RWMS Expanded Operations Alternative 


\subsubsection{Air Pathway Scenario Uncertainty}

Scenario uncertainty is assessed by evaluating alternative exposure scenarios. Alternative scenarios for the Area 5 RWMS are the transient occupancy, resident farmer, and open rangeland scenarios. The Area 3 RWMS alternative scenario is limited to the transient occupancy scenario.

The transient occupancy scenario assumes that a visitor is on site 2,000 hour $\mathrm{y}^{-1}$ engaged in light activity. The open rangeland scenarios assume that a ranch is located at Cane Spring or the closest NNSS boundary. In addition to airborne emissions, the ranch resident is exposed through consumption of beef and milk from cattle grazing on the RWMS. Contaminated fodder consumption is limited by the productivity and area of the site.

The mean and $95^{\text {th }}$ percentile annual TEDs, when available, are less than the performance objective for all alternative exposure scenarios (Table 3-2). The highest TED is observed for the resident farmer scenario. Exposure scenario uncertainty contributes significant uncertainty, but a range of reasonable scenarios for the site indicates that there is little probability of exceeding the performance objective.

Table 3-2. Maximum air pathway TED results for alternative scenarios.

\begin{tabular}{|c|c|c|c|c|c|}
\hline RWMS & Scenario & Alternative & $\begin{array}{l}\text { Mean } \\
\text { TED } \\
(\mathrm{mSv})\end{array}$ & $\begin{array}{c}95^{\text {th }} \\
\text { Percentile } \\
(\mathrm{mSv})\end{array}$ & $\begin{array}{l}\text { Time of } \\
\text { Maximum } \\
\text { (y) }\end{array}$ \\
\hline \multirow{8}{*}{ Area 5} & \multirow{2}{*}{ Transient Occupancy } & No Action & $4.8 \mathrm{E}-5$ & $1.8 \mathrm{E}-4$ & 1,000 \\
\hline & & Expanded Operations & $4.6 \mathrm{E}-5$ & 1.7E-4 & 1,000 \\
\hline & \multirow{2}{*}{ Resident Farmer } & No Action & $1.8 \mathrm{E}-4$ & $6.9 \mathrm{E}-4$ & 1,000 \\
\hline & & Expanded Operations & $1.8 \mathrm{E}-4$ & $6.4 \mathrm{E}-4$ & 1,000 \\
\hline & \multirow{2}{*}{$\begin{array}{c}\text { Open Rangeland, Cane } \\
\text { Spring }\end{array}$} & No Action & $1.4 \mathrm{E}-8$ & NA & 100 \\
\hline & & Expanded Operations & $4.2 \mathrm{E}-8$ & NA & 100 \\
\hline & \multirow{2}{*}{$\begin{array}{c}\text { Open Rangeland, NNSS } \\
\text { Boundary }\end{array}$} & No Action & $2.0 \mathrm{E}-7$ & NA & 100 \\
\hline & & Expanded Operations & $5.7 \mathrm{E}-7$ & NA & 100 \\
\hline Area 3 & Transient Occupancy & Expanded Operations & $1.4 \mathrm{E}-6$ & $4.3 \mathrm{E}-6$ & 1,000 \\
\hline
\end{tabular}

$\mathrm{NA}-$ not available, insufficient non-zero realizations to calculate $95^{\text {th }}$ percentile

\subsubsection{All-Pathways Results}

Compliance with the all-pathways performance objective of $0.25 \mathrm{mSv}$ in a year is assessed for the resident scenario for the Area 5 RWMS. Compliance at the Area 3 RWMS is assessed for the resident farmer scenario.

The mean and $95^{\text {th }}$ percentile all-pathways annual TEDs are less than the performance objective for the No Action and Expanded Operations Alternatives (Table 3-3). The No Action and Expanded Operations Alternative produce similar TEDs at the Area 5 RWMS because the TED is proportional to the waste concentration, which is similar for both alternatives. 
Table 3-3. Maximum all-pathway annual TED results for the No Action and Expanded Operations Alternatives.

\begin{tabular}{|c|c|c|c|c|c|}
\hline \multirow{2}{*}{ RWMS } & Scenario & Alternative & $\begin{array}{c}\text { Mean } \\
\text { TED } \\
(\mathrm{mSv})\end{array}$ & $\begin{array}{c}\text { 95 } \\
\text { Percentile } \\
(\mathrm{mSv})\end{array}$ & $\begin{array}{c}\text { Time of } \\
\text { Maximum } \\
(\mathrm{y})\end{array}$ \\
\hline \multirow{2}{*}{ Area 5 } & \multirow{2}{*}{ Resident } & No Action & $6.7 \mathrm{E}-4$ & $2.4 \mathrm{E}-3$ & 1,000 \\
\cline { 3 - 6 } & & Expanded Operations & $6.7 \mathrm{E}-4$ & $2.4 \mathrm{E}-3$ & 1,000 \\
\hline Area 3 & Resident Farmer & Expanded Operations & $3.4 \mathrm{E}-3$ & NA & 100 \\
\hline
\end{tabular}

NA - not available, insufficient non-zero realizations to calculate $95^{\text {th }}$ percentile

The maximum mean resident TED at the Area 5 RWMS occurs at 1,000 y for the Expanded Operations Alternative (Figure 3-8). Similar results are observed for the No Action Alternative. The TED at $1,000 \mathrm{y}$ is contributed predominantly by ${ }^{210} \mathrm{~Pb}$ and ${ }^{229} \mathrm{Th}$. The $5^{\text {th }}$ percentile TED is zero over $1,000 \mathrm{y}$ because the probability of institutional controls remaining effective over $1,000 \mathrm{y}$ is greater than 5 percent.

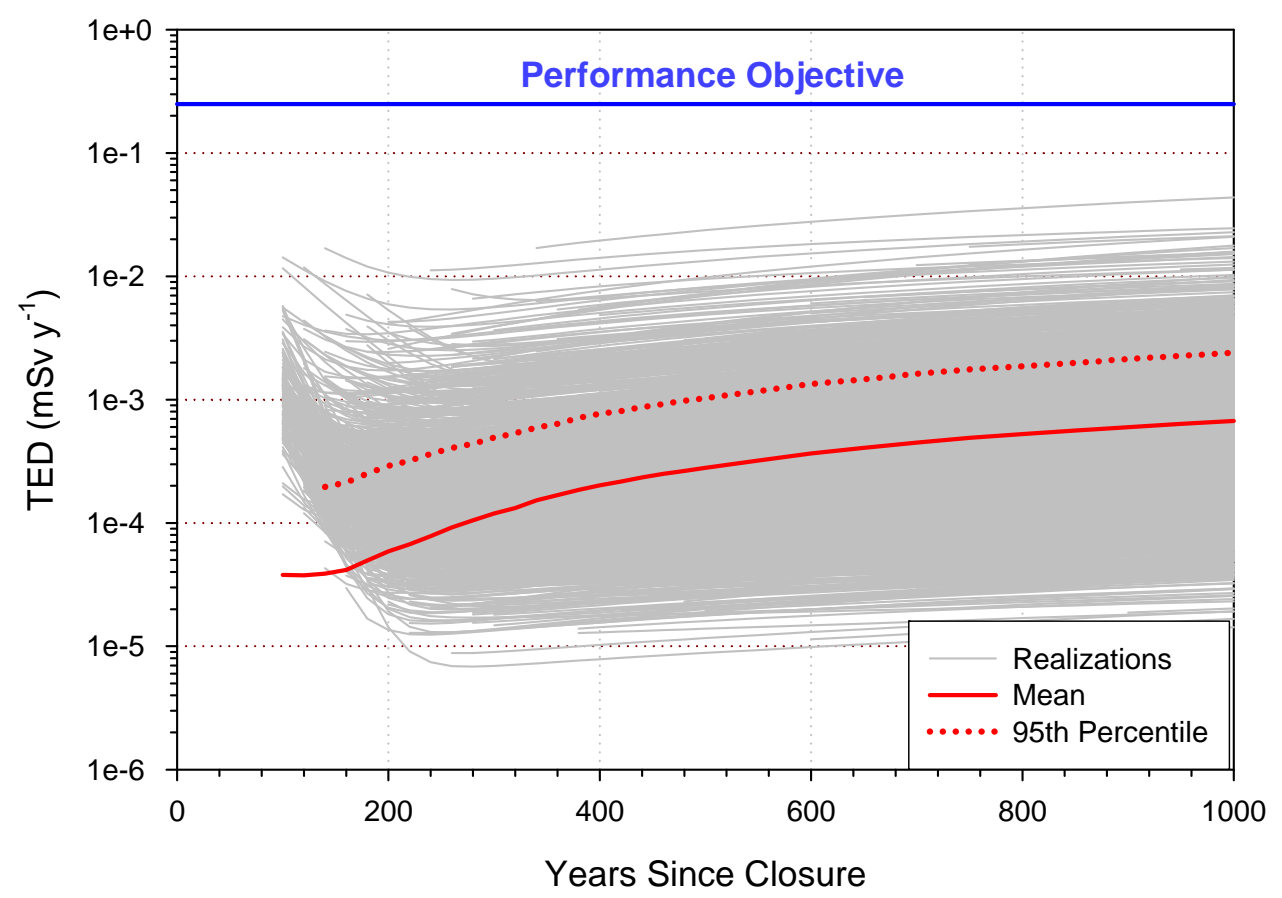

Figure 3-8. Time history of the resident all-pathway annual TED for the Area 5 RWMS Expanded Operations Alternative

The maximum mean all-pathways TED for the resident farmer at the Area 3 RWMS occurs at $100 \mathrm{y}$ for the Expanded Operations Alternative (Figure 3-9). The TED at $100 \mathrm{y}$ is contributed predominantly by ${ }^{3} \mathrm{H}$ ingested in agricultural products. The $5^{\text {th }}$ percentile TED is zero over $1,000 \mathrm{y}$ because the probability of institutional controls remaining effective over 1,000 $\mathrm{y}$ is greater than 5 percent. 


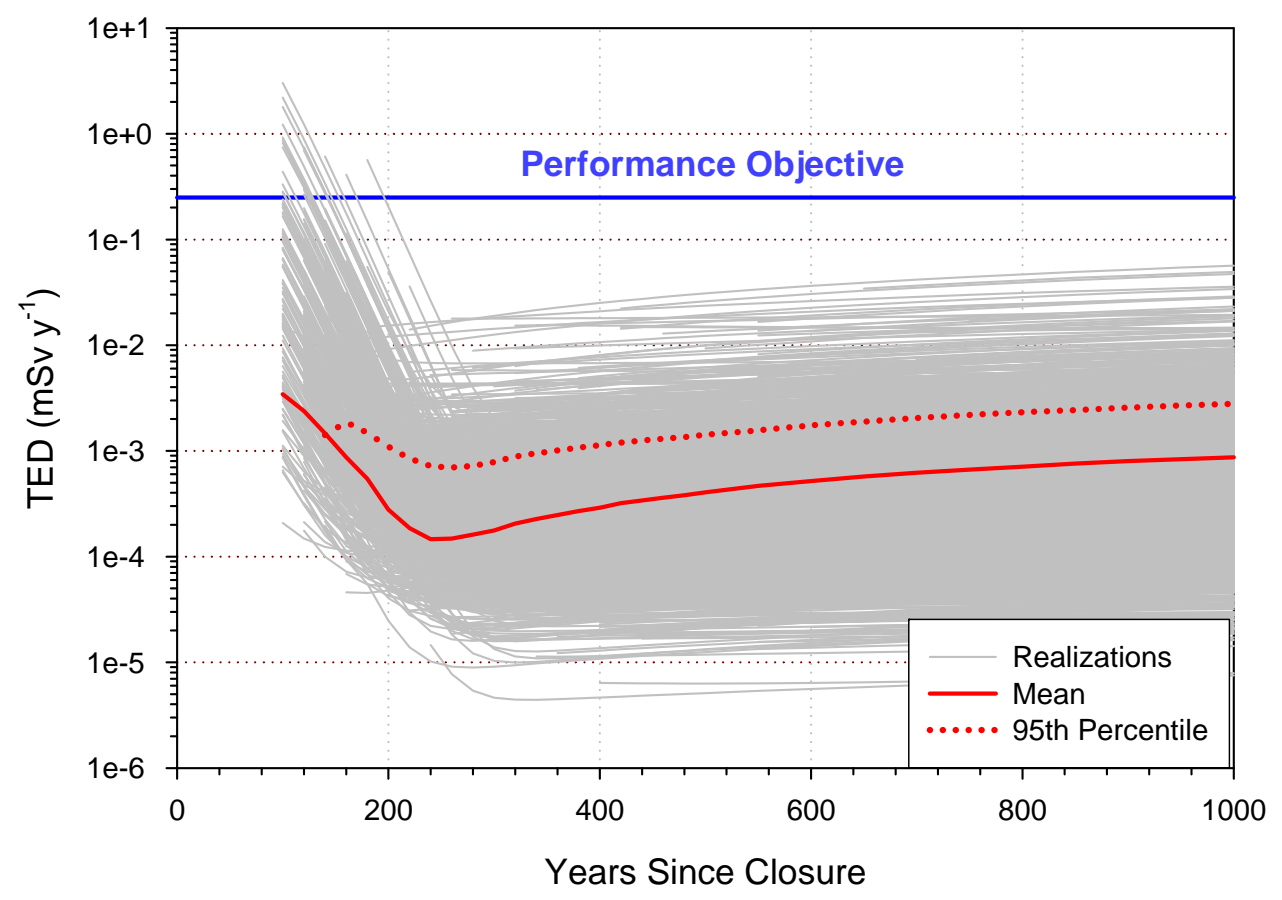

Figure 3-9. Time history of the resident all-pathway annual TED for the Area 3 RWMS Expanded Operations Alternative

\subsubsection{All-Pathways Parameter Uncertainty}

The all-pathways TED parameter uncertainty is assessed using 5,000 LHS realizations. Parameter uncertainty is assessed for the Expanded Operations Alternative at 1,000 y for the Area 5 RWMS and at $100 \mathrm{y}$ for the Area 3 RWMS.

The Area 5 RWMS resident TED at 1,000 y is skewed to the right and relatively symmetric when log transformed (Figure 3-10). The ecdf indicates that there is a very low probability of exceeding the performance objective, as no realization exceeds the performance objective. Approximately 11 percent of the realizations are zero at 1,000 $\mathrm{y}$. The zero TED values occur for realizations where institutional controls remain effective throughout the 1,000-y compliance period.

Greater than 97 percent of the Area 3 RWMS resident farmer TED realizations at $100 \mathrm{y}$ are zero due to the effectiveness of institutional controls. The remaining non-zero realizations $(\mathrm{n}=109)$ are relatively symmetrically distributed when log transformed (Figure 3-11). The ecdf indicates that there is a small probability of exceeding the performance objective in the unlikely event that institutional controls fail and a resident farmer arrives at the site boundary within $100 \mathrm{y}$ of closure. The simulated overall probability of meeting the performance objective is 99.8 percent. 

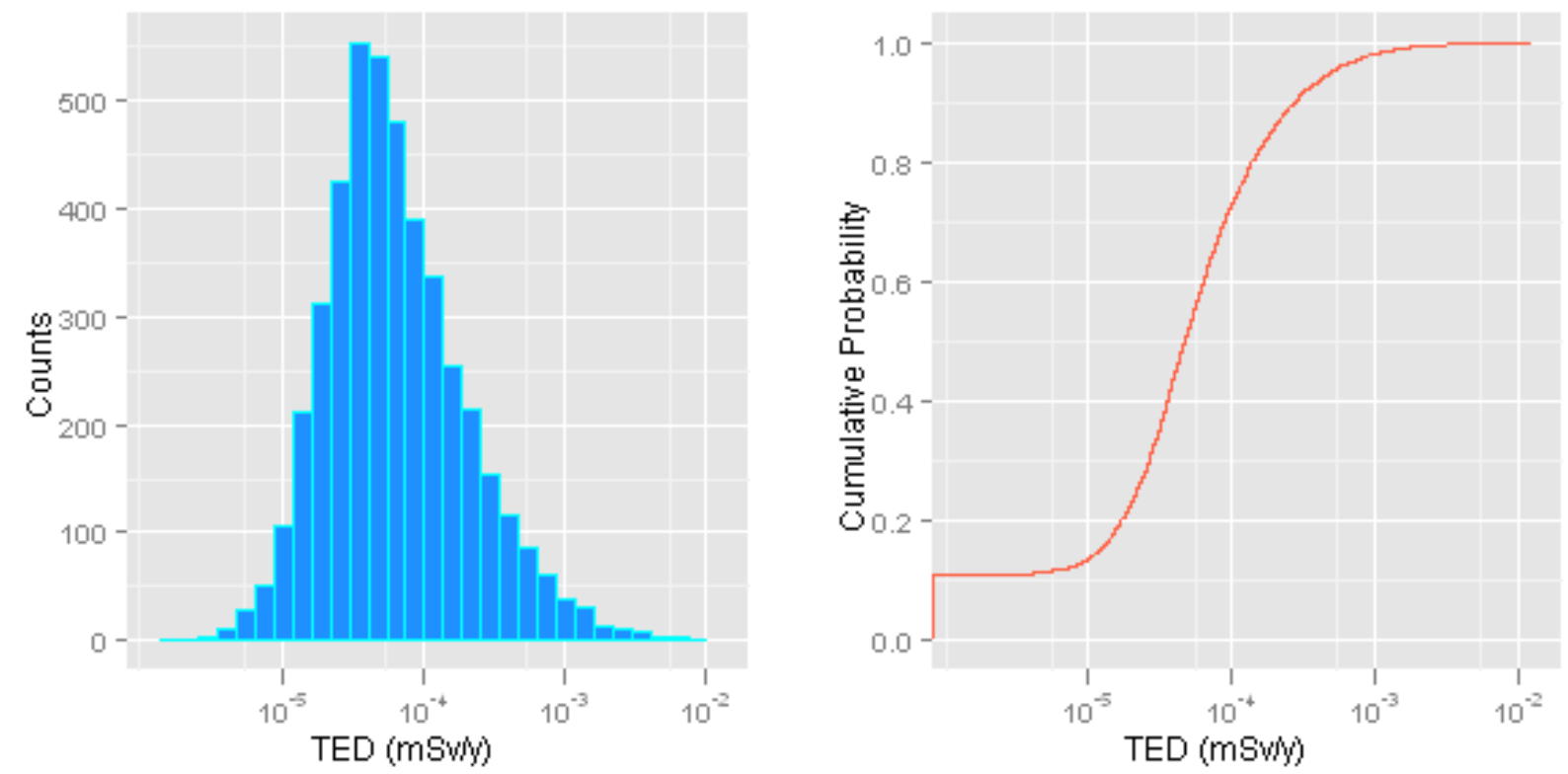

Figure 3-10. Histogram of non-zero values (left) and empirical cumulative distribution function (right) of the resident all-pathways TED at 1,000 y for the Area 5 RWMS Expanded Operations Alternative
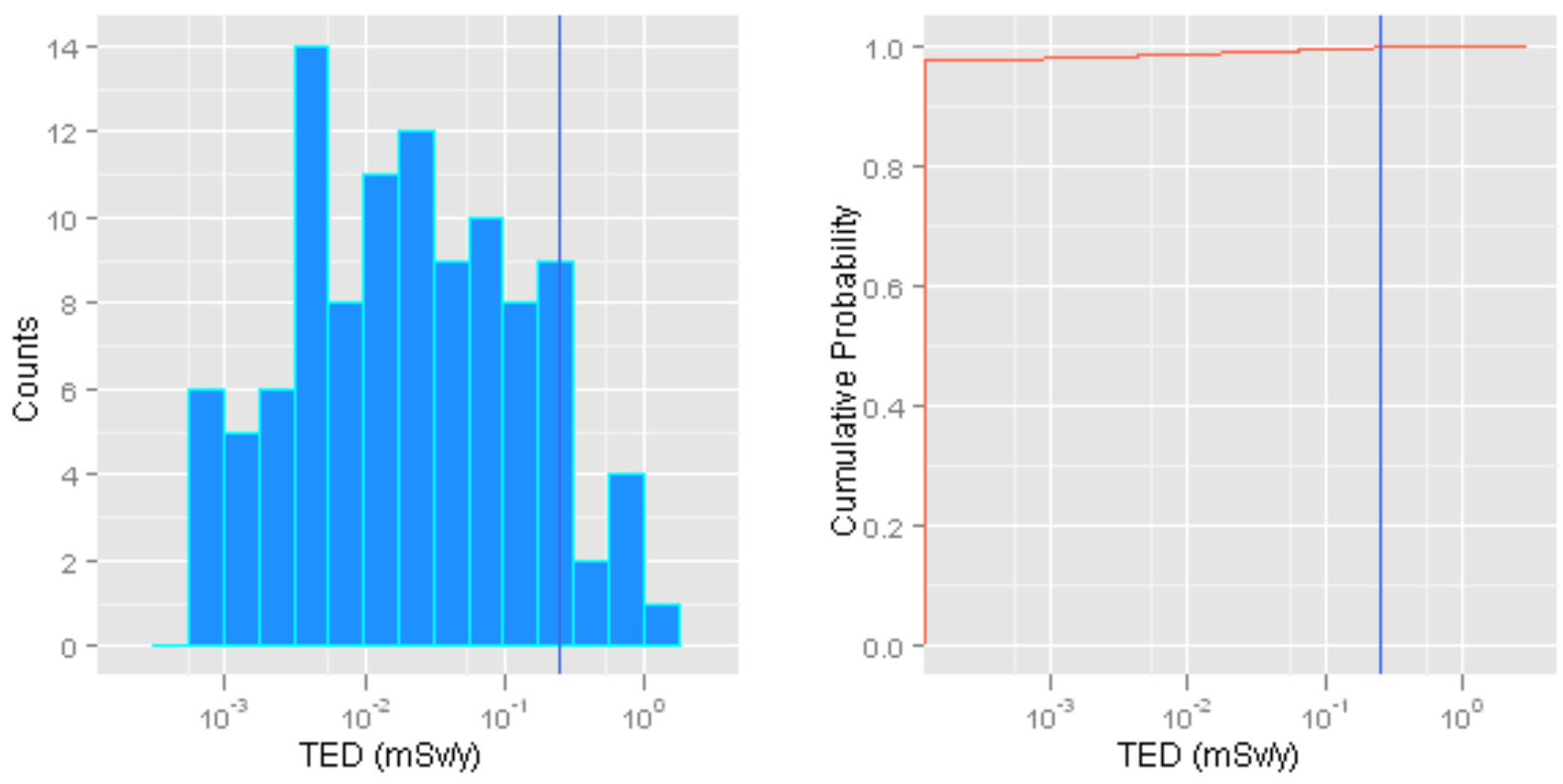

Figure 3-11. Histogram of non-zero values (left) and empirical cumulative distribution function (right) of the resident farmer all-pathways TED at $100 \mathrm{y}$ for the Area 3 RWMS Expanded Operations Alternative. Performance objective shown as blue vertical line. 
In addition to the requirement that a disposal site meet the performance objectives, DOE O 435.1 requires that releases be maintained as low as reasonably achievable (ALARA). The results contained in this report are preliminary results not yet subject to the ALARA process.

Periodically during operations and prior to final closure, ALARA analyses will be conducted to identify cost-effective options (e.g., constructing a thicker closure cap, adding a barrier, ceasing operations) that may reduce doses further. Any and all options will be carefully reviewed by the Federal Low-Level Waste Review Group before the site makes a final closure decision.

\subsubsection{All-Pathways Scenario Uncertainty}

The alternative all-pathways scenarios for the Area 5 RWMS are the transient occupancy, resident farmer, and open rangeland scenarios. The Area 3 RWMS alternative scenario is limited to the transient occupancy scenario.

The mean and $95^{\text {th }}$ percentile TEDs, when available, are less than the performance objective for all alternative exposure scenarios (Table 3-4). The highest TED is observed for the resident farmer scenario. Exposure scenario uncertainty contributes significant uncertainty, but a range of reasonable scenarios for the site indicates that there is little probability of exceeding the performance objective.

Table 3-4. Maximum all-pathway annual TED results for alternative scenarios

\begin{tabular}{|c|c|c|c|c|c|}
\hline RWMS & Scenario & Alternative & $\begin{array}{c}\text { Mean } \\
\text { TED } \\
\left(\mathrm{mSv} \mathrm{y}^{-1}\right)\end{array}$ & $\begin{array}{c}95^{\text {th }} \\
\text { Percentile } \\
\left(\mathrm{mSv} \mathrm{y}^{-1}\right)\end{array}$ & $\begin{array}{l}\text { Time of } \\
\text { Maximum } \\
\text { (y) }\end{array}$ \\
\hline \multirow{8}{*}{ Area 5} & \multirow{2}{*}{ Transient Occupancy } & No Action & $3.7 E-3$ & $8.4 \mathrm{E}-3$ & 1,000 \\
\hline & & Expanded Operations & $3.7 E-3$ & $8.9 E-3$ & 1,000 \\
\hline & \multirow{2}{*}{ Resident Farmer } & No Action & 0.017 & 0.051 & 1,000 \\
\hline & & Expanded Operations & 0.017 & NA & 100 \\
\hline & \multirow{2}{*}{$\begin{array}{l}\text { Open Rangeland, } \\
\text { Cane Spring }\end{array}$} & No Action & $4.7 \mathrm{E}-3$ & NA & 100 \\
\hline & & Expanded Operations & $6.8 \mathrm{E}-3$ & NA & 100 \\
\hline & \multirow{2}{*}{$\begin{array}{l}\text { Open Rangeland, } \\
\text { NNSS Boundary }\end{array}$} & No Action & $5.4 \mathrm{E}-3$ & NA & 100 \\
\hline & & Expanded Operations & $8.6 \mathrm{E}-3$ & NA & 100 \\
\hline Area 3 & Transient Occupancy & Expanded Operations & $1.2 \mathrm{E}-3$ & $3.7 \mathrm{E}-3$ & 1,000 \\
\hline
\end{tabular}

NA - not available, insufficient non-zero realizations to calculate $95^{\text {th }}$ percentile

\subsection{3 ${ }^{222}$ Rn Flux Density Results}

The performance objectives limit the radon-222 $\left({ }^{222} \mathrm{Rn}\right)$ flux density, averaged over all disposal units, to less than 0.74 becquerels per square meter per second $\left(\mathrm{Bq} \mathrm{m}^{-2} \mathrm{~s}^{-1}\right)$. The mean and $95^{\text {th }}$ percentile ${ }^{222} \mathrm{Rn}$ flux densities are less than the performance objectives at the Area 3 and Area 5 RWMSs for the No Action and Expanded Operations Alternatives (Table 3-5). The Area 5 RWMS flux density is similar for the two alternatives because the waste activity concentration is similar for both cases. The Area 3 RWMS flux density is significantly less than estimated for the Area 5 RWMS. 
Table 3-5. Maximum ${ }^{222} \mathrm{Rn}$ flux density results for the No Action and Expanded Operations Alternatives

\begin{tabular}{|c|c|c|c|c|}
\hline \multirow{2}{*}{ RWMS } & Alternative & $\begin{array}{c}\text { Mean Flux Density } \\
\left(\mathrm{Bq} \mathrm{m}^{-2} \mathrm{~s}^{-1}\right)\end{array}$ & $\begin{array}{c}95^{\text {th }} \text { Percentile } \\
\left(\mathrm{Bq} \mathrm{m}^{-2} \mathrm{~s}^{-1}\right)\end{array}$ & $\begin{array}{c}\text { Time of } \\
\text { Maximum (y) }\end{array}$ \\
\hline \multirow{2}{*}{ Area 5 } & No Action & 0.13 & 0.26 & 1,000 \\
\cline { 2 - 5 } & Expanded Operations & 0.13 & 0.28 & 1,000 \\
\hline Area 3 & Expanded Operations & 0.034 & 0.099 & 1,000 \\
\hline
\end{tabular}

The ${ }^{222} \mathrm{Rn}$ flux density is increasing throughout the 1000-y compliance period as radium-226 $\left({ }^{226} \mathrm{Ra}\right)$ is produced by radioactive decay of its parent radionuclides (Figure 3-12). Similar trends are observed for the Area 5 RWMS No Action Alternative and the Area 3 RWMS Expanded Operations Alternative.

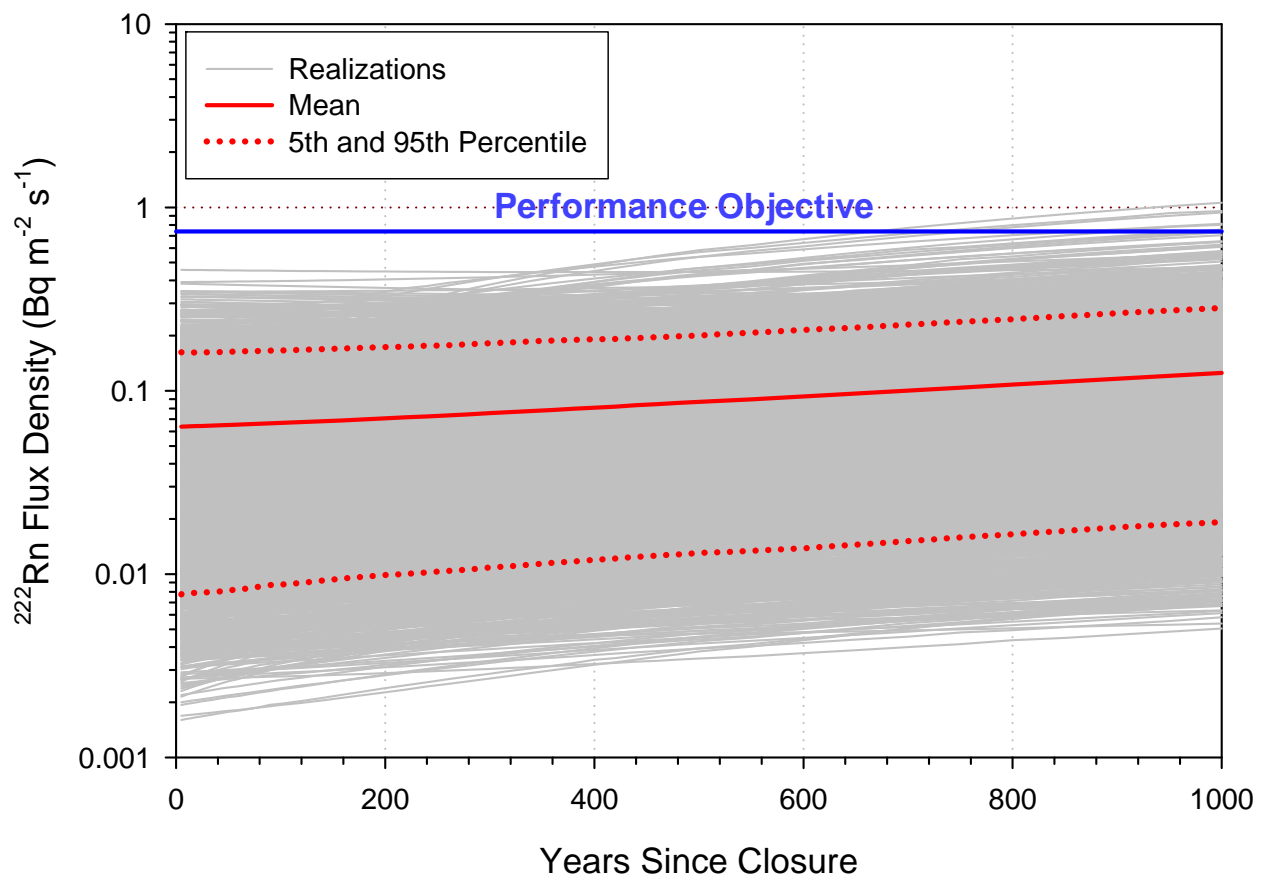

Figure 3-12. Time history of the ${ }^{222} \mathrm{Rn}$ flux density for the Area 5 RWMS Expanded Operations Alternative

\subsubsection{1 $\quad{ }^{222}$ Rn Flux Density Parameter Uncertainty}

Parameter uncertainty for the ${ }^{222} \mathrm{Rn}$ flux density is assessed with 5,000 LHS realizations. The Area 5 RWMS ${ }^{222}$ Rn flux density at 1,000 y for the Expanded Operations Alternative is slightly skewed to the left when log transformed (Figure 3-13). Seven realizations exceed the performance objective at 1,000 y, indicating there is a high probability (i.e., 99.9 percent) of meeting the performance objective. The Area 3 RWMS Expanded Operations Alternative ${ }^{222} \mathrm{Rn}$ flux density at 1,000 y is much less, and no realization exceeds the performance objective (Figure 3-14). 
Again, these results are preliminary and not yet subject to the ALARA process. Any and all cost-effective options reducing flux density will be carefully reviewed by the Federal Low-Level Waste Review Group before the site makes a final closure decision.
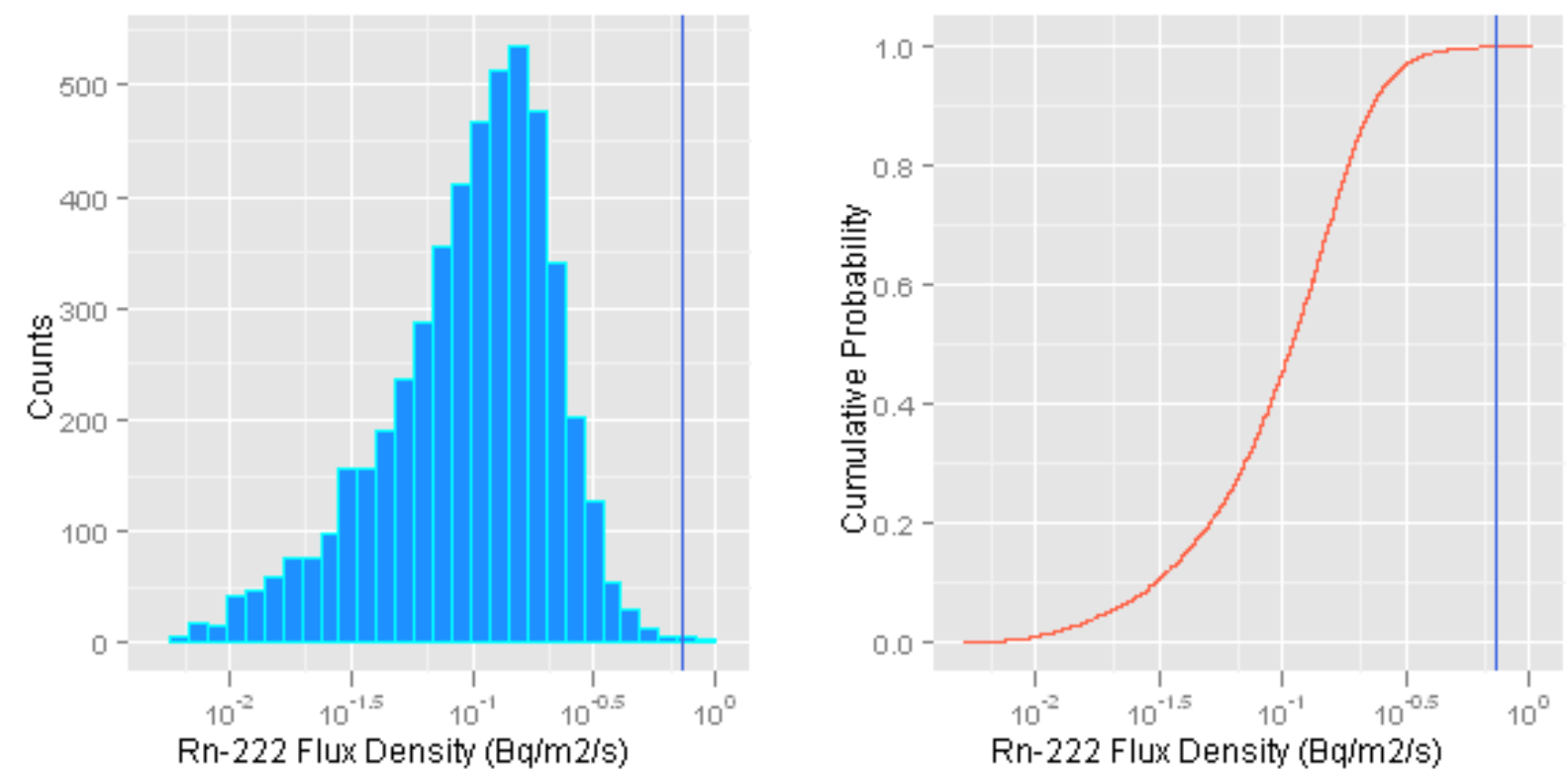

Figure 3-13. Histogram of non-zero values (left) and empirical cumulative distribution function (right) of the ${ }^{222} \mathrm{Rn}$ flux density at 1,000 y for the Area 5 RWMS Expanded Operations Alternative. Performance objective shown as blue vertical line.
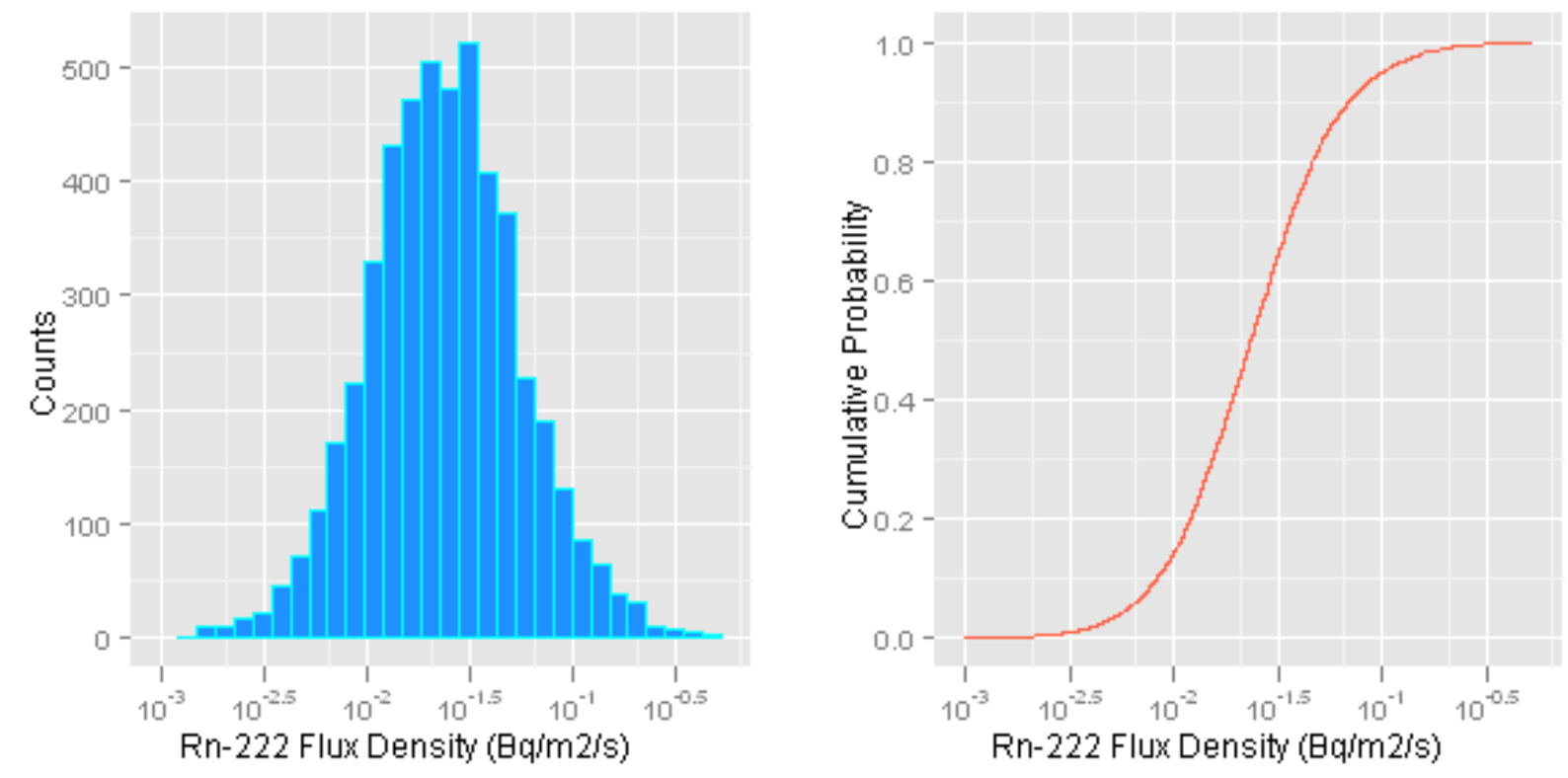

Figure 3-14. Histogram of non-zero values (left) and empirical cumulative distribution function (right) of the ${ }^{222} \mathrm{Rn}$ flux density at 1,000 y for the Area 3 RWMS Expanded Operations Alternative 


\subsubsection{Intruder Results}

Land-use restrictions planned for the NNSS are assumed to prevent long-term chronic intruder exposure. Acute or short-term exposures are assumed to be possible after the effectiveness of institutional controls is degraded. Two acute intruder scenarios are evaluated for the Area 3 RWMS: a drilling scenario and a construction scenario. Results are reported for the SLB disposal units as these are the units assumed to receive future waste.

The mean and $95^{\text {th }}$ percentile TEDs received by an intruder at the Area 5 RWMS SLB disposal units for the No Action and Expanded Operations Alternative are less than the $5 \mathrm{mSv}$ dose limit (Table 3-6). The construction scenario TED is much higher than the drilling scenario result, and the $95^{\text {th }}$ percentile is approximately 44 percent of the limit. The results are similar for the two alternatives because the waste activity concentrations are similar.

Table 3-6. Maximum acute intruder scenario results for the No Action and Expanded Operations Alternatives at the Area 5 RWMS SLB disposal units

\begin{tabular}{|c|c|c|c|c|c|}
\hline \multirow{2}{*}{ Scenario } & \multirow{2}{*}{ Disposal Unit } & Alternative & $\begin{array}{c}\text { Mean TED } \\
(\mathrm{mSv})\end{array}$ & $\begin{array}{c}95^{\text {th }} \text { Percentile } \\
(\mathrm{mSv})\end{array}$ & $\begin{array}{c}\text { Time of } \\
\text { Maximum (y) }\end{array}$ \\
\hline \multirow{2}{*}{ Drilling } & \multirow{2}{*}{ SLB } & No Action & $1.3 \mathrm{E}-3$ & $2.3 \mathrm{E}-3$ & 1,000 \\
\cline { 3 - 6 } & \multirow{2}{*}{ Construction } & Expanded Operations & $1.3 \mathrm{E}-3$ & $2.5 \mathrm{E}-3$ & 1,000 \\
\cline { 3 - 6 } & \multirow{2}{*}{ SLB } & No Action & 1.1 & 2.1 & 1,000 \\
\cline { 3 - 6 } & Expanded Operations & 1.1 & 2.3 & 1,000 \\
\hline
\end{tabular}

The mean construction intruder TED for the Area 5 RWMS Expanded Operations Alternative is increasing throughout the compliance period and reaches its maximum at 1,000 y (Figure 3-15). The highest individual realizations occur after closure, but because of the high likelihood that institutional controls will prevent intrusion in the near-term, the mean TED remains low for a few hundred years after closure. The probability of meeting the $5 \mathrm{mSv}$ acute dose limit is 99.5 percent. 


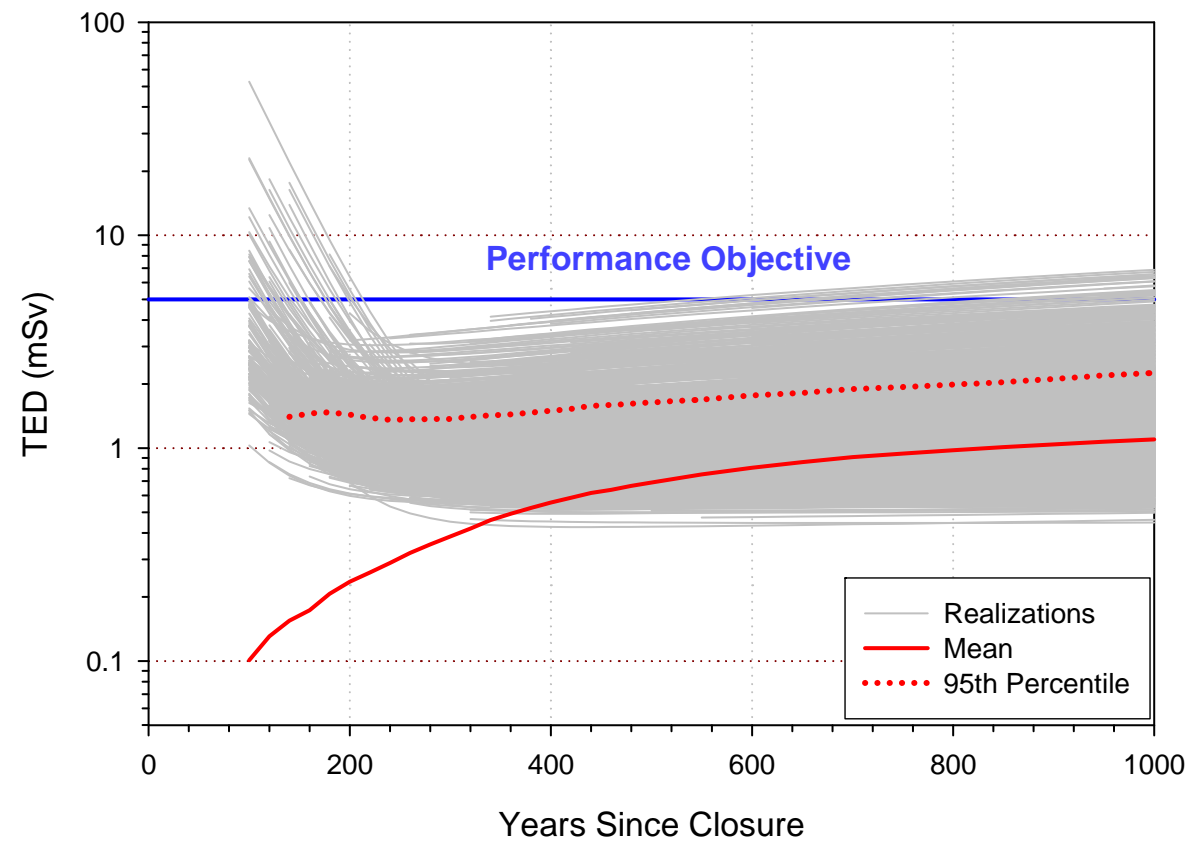

Figure 3-15. Time history of the acute construction scenario TED for the Area 5 RWMS SLB disposal units Expanded Operations Alternative

\subsubsection{Intruder Scenario Uncertainty}

Results for chronic intrusion scenarios are reported to assess the significance of scenario uncertainty for intruder doses. A chronic postdrilling and intruder-agriculture scenario are evaluated. The postdrilling scenario assumes a resident lives on a home site contaminated with drill cuttings and consumes limited quantities of agricultural products produced on site. The intruder-agriculture scenario assumes a resident lives on a home site contaminated by construction of a basement and consumes limited quantities of agricultural products produced on site. The reported TEDs are multiplied by the probability of intrusion as estimated by elicitation of a panel of subject matter experts.

The mean chronic intruder TED is less than the $1 \mathrm{mSv}$ dose limit for all scenarios and alternatives (Table 3-7). The $95^{\text {th }}$ percentile TEDs exceed the limit for the intruder-agriculture scenario at the Area 5 RWMS for both alternatives. The Area 3 RWMS TEDs are much less than the estimated for the Area 5 RWMS. The high TEDs for the Area 5 RWMS are due in part to the thinner closure cover, which allows direct intrusion into waste during excavation of the basement. 
Table 3-7. Maximum chronic intruder results weighted with the probability of intrusion for the No Action and Expanded Operations Alternatives at the Area 3 and Area 5 RWMSs

\begin{tabular}{|c|c|c|c|c|c|c|}
\hline RWMS & $\begin{array}{c}\text { Disposal } \\
\text { Unit }\end{array}$ & Scenario & Alternative & $\begin{array}{c}\text { Mean } \\
\text { TED } \\
(\mathrm{mSv})\end{array}$ & $\begin{array}{c}95^{\text {th }} \\
\text { Percentile } \\
\text { (mSv y) }\end{array}$ & $\begin{array}{l}\text { Time of } \\
\text { Maximum } \\
\text { (y) }\end{array}$ \\
\hline \multirow{4}{*}{ Area 5} & \multirow{4}{*}{ SLB } & \multirow[b]{2}{*}{ Postdrilling } & No Action & $5.5 \mathrm{E}-3$ & $1.8 \mathrm{E}-2$ & 1,000 \\
\hline & & & $\begin{array}{l}\text { Expanded } \\
\text { Operations }\end{array}$ & $5.0 \mathrm{E}-3$ & 1.6E-2 & 1,000 \\
\hline & & \multirow{2}{*}{$\begin{array}{l}\text { Intruder- } \\
\text { Agriculture }\end{array}$} & No Action & 0.38 & 1.3 & 1,000 \\
\hline & & & $\begin{array}{l}\text { Expanded } \\
\text { Operations }\end{array}$ & 0.35 & 1.1 & 1,000 \\
\hline \multirow{2}{*}{ Area 3} & \multirow{2}{*}{ U-3ah/at } & Postdrilling & $\begin{array}{l}\text { Expanded } \\
\text { Operations }\end{array}$ & $4.2 \mathrm{E}-6$ & NA & 120 \\
\hline & & $\begin{array}{c}\text { Intruder- } \\
\text { Agriculture }\end{array}$ & $\begin{array}{l}\text { Expanded } \\
\text { Operations }\end{array}$ & $2.8 \mathrm{E}-5$ & $8.6 \mathrm{E}-5$ & 1,000 \\
\hline
\end{tabular}

NA - not available, insufficient non-zero realizations to calculate $95^{\text {th }}$ percentile

\subsection{Composite Analysis Results}

The CA assesses the TED to a future resident at the $100 \mathrm{~m}$ (330 ft) site boundary from the total RWMS inventory, including pre-1988 disposed waste, and other sources of residual radioactive contamination. The only important additional source included for the Area 5 RWMS is the pre-1988 waste inventory. The CA TED for the Area 3 RWMS includes contributions from the pre-1988 waste, the HORNET ground zero contaminated soil site, located at the Area 3 RWMS boundary, and the airborne emissions from numerous soil sites contaminated by aboveground nuclear tests throughout Yucca Flat. The CA TED does not currently include dose from groundwater contaminated by belowground nuclear testing as this is the subject of ongoing research.

The mean and $95^{\text {th }}$ percentile CA TEDs for the No Action and Expanded Operations Alternatives at the Area 3 and Area $5 \mathrm{RWMS}$ are below the $0.3 \mathrm{mSv}$ annual dose constraint and the $1 \mathrm{mSv}$ annual dose limit (Table 3-8). The Area 5 RWMS CA TED is predominantly from ${ }^{210} \mathrm{~Pb},{ }^{238} \mathrm{U}$, and ${ }^{229}$ Th in disposed waste.

The Area 5 RWMS CA TED for the No Action Alternative is greater than the Expanded Operations TED. The greater dose is caused by a higher waste concentration for the No Action Alternative. Pre-1988 waste has a higher ${ }^{234} U$ concentration than post-1988 waste. Future waste is assumed to have a similar concentration as post-1988 waste. Therefore, future waste disposal has the effect of diluting ${ }^{234} \mathrm{U}$ concentration, and the increased future waste volume under the Expanded Operations Alternative results in a lower ${ }^{234} \mathrm{U}$ concentration. The lower ${ }^{234} \mathrm{U}$ concentration for the Expanded Operations Alternative lowers the ${ }^{210} \mathrm{~Pb}$ dose at $1,000 \mathrm{y}$. 
Table 3-8. Maximum composite analysis results for the No Action and Expanded Operations Alternatives

\begin{tabular}{|c|c|c|c|c|c|}
\hline \multirow{2}{*}{ RWMS } & Scenario & Alternative & $\begin{array}{c}\text { Mean TED } \\
\left(\mathrm{mSv} \mathrm{y^{-1 }}\right)\end{array}$ & $\begin{array}{c}95^{\text {th }} \\
\text { Percentile } \\
\left(\mathrm{mSv}^{-1}\right)\end{array}$ & $\begin{array}{c}\text { Time of } \\
\text { Maximum (y) }\end{array}$ \\
\hline \multirow{2}{*}{ Area 5 } & Resident & No Action & $8.5 \mathrm{E}-4$ & $2.8 \mathrm{E}-3$ & 1,000 \\
\cline { 3 - 6 } & $\begin{array}{c}\text { Expanded } \\
\text { Operations }\end{array}$ & $7.7 \mathrm{E}-4$ & $2.6 \mathrm{E}-3$ & 1,000 \\
\hline Area 3 & Resident Farmer & $\begin{array}{c}\text { Expanded } \\
\text { Operations }\end{array}$ & 0.052 & 0.091 & 1,000 \\
\hline
\end{tabular}

The Area 3 RWMS CA TED is significantly higher than estimated for the Area 5 RWMS. The Area 3 RWMS CA TED is predominantly from inhalation of plutonium-239 $\left({ }^{239} \mathrm{Pu}\right)$ in soil resuspended from the HORNET ground zero contaminated soil site.

The mean Area 5 RWMS CA TED is increasing throughout the compliance period and reaches a maximum at 1,000 y (Figure 3-16). No realization exceeds the $0.3 \mathrm{mSv}$ dose constraint.

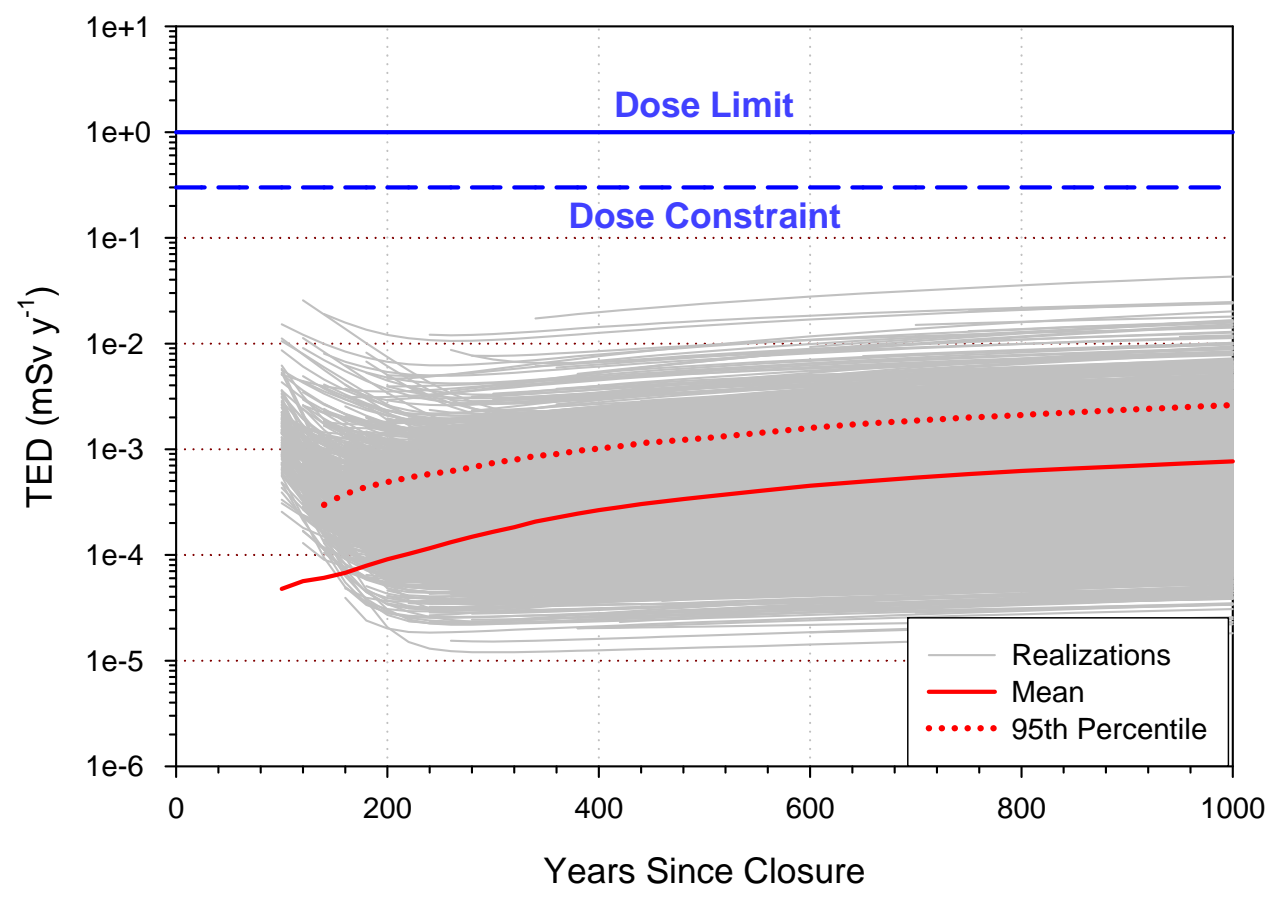

Figure 3-16. Time history of the composite analysis TED for the Area 5 RWMS Expanded Operations Alternative 


\subsection{Conclusions}

The post-closure performance of the Area 3 RWMS and Area 5 RWMS are evaluated for the No Action and Expanded Operations Alternatives using current PA and CA methods and models. Both the No Action and Expanded Operations Alternatives were found to have a reasonable expectation of meeting all DOE O 435.1 performance objectives. No significant difference between the two alternatives is found because risks are assessed for residents at the RWMS boundary where risk is more closely related to waste concentration than total waste inventory. Results for the CA also indicate that the dose constraint and dose limit can be met for both alternatives. 


\subsection{References}

Bechtel Nevada, 2001. Composite Analysis for the Area 5 Radioactive Waste Management Site at the Nevada Test Site, Nye County, Nevada. DOE/NV--594. Las Vegas, NV.

September 2001.

Bechtel Nevada, 2006. Addendum 2 to the Performance Assessment for the Area 5 Radioactive Waste Management Site at the Nevada Test Site, Nye County, Nevada.

DOE/NV/11718--176-ADD2. Las Vegas, NV. January 2006.

Black, P., K. Black, L. Stahl, M. Hooten, T. Stockton, and D. Neptune, 2001. Assessing the Probability of Inadvertent Human Intrusion at the Nevada Test Site Radioactive Waste Management Sites. DOE/NV--593, Vols. I and II. Neptune and Company, Los Alamos, NM.

BN, see Bechtel Nevada.

DOE, see U.S. Department of Energy

Eckerman, K. F., and J. C. Ryman, 1993. External Exposure to Radionuclides in Air, Water, and Soil. Federal Guidance Report 11. U.S. Environmental Protection Agency, Washington, D.C.

Eckerman, K. F., A. B. Wolbarst, and A. C. B. Richardson, 1998. Limiting Values of Radionuclide Intake and Air Concentration and Dose Conversion Factors for Inhalation, Submersion and Ingestion. Federal Guidance Report 12. U.S. Environmental Protection Agency, Washington, D.C.

National Security Technologies, LLC, 2008. 2007 Annual Summary Report for the Area 3 and Area 5 Radioactive Waste Management Sites at the Nevada Test Site, Nye County, Nevada: Review of the Performance Assessments and Composite Analyses. DOE/NV/25946--346. Las Vegas, NV. January 2008.

National Security Technologies, LLC, 2009. 2008 Annual Summary Report for the Area 3 and Area 5 Radioactive Waste Management Sites at the Nevada Test Site, Nye County, Nevada: Review of the Performance Assessments and Composite Analyses. DOE/NV/25946--691. Las Vegas, NV. March 2009.

National Security Technologies, LLC, 2010. 2009 Annual Summary Report for the Area 3 and Area 5 Radioactive Waste Management Sites at the Nevada Test Site, Nye County, Nevada: Review of the Performance Assessments and Composite Analyses. DOE/NV/25946--893. Las Vegas, NV. March 2010.

National Security Technologies, LLC, 2011. 2010 Annual Summary Report for the Area 3 and Area 5 Radioactive Waste Management Sites at the Nevada National Security Site, Nye County, Nevada: Review of the Performance Assessments and Composite Analyses. DOE/NV/25946--1158. Las Vegas, NV. March 2011. 
NSTec, see National Security Technologies, LLC.

Shott, G. J., and V. Yucel, 2009. Optimization of the Area 5 Radioactive Waste Management Site Closure Cover. DOE/NV/25946--695. National Security Technologies, LLC, Las Vegas, NV. April 2009.

Shott, G. J., L. E. Barker, S. E. Rawlinson, M. J. Sully, and B. A. Moore, 1998. Performance Assessment for the Area 5 Radioactive Waste Management Site at the Nevada Test Site, Nye County, Nevada, Rev. 2.1. DOE/NV/11718--176/UC-721. Bechtel Nevada, Las Vegas, NV. January 1998.

Shott, G. J., V. Yucel, M. J. Sully, L. E. Barker, S. E. Rawlinson, and B. A. Moore, 2001. Performance Assessment/Composite Analysis for the Area 3 Radioactive Waste Management Site at the Nevada Test Site, Nye County, Nevada, Rev. 2.1. DOE/NV--491Rev 2.1. Bechtel Nevada, Las Vegas, NV. December 2001.

U.S. Department of Energy, 2001. Radioactive Waste Management. DOE O 435.1 Chg 1, Washington, D.C.

U.S. Department of Energy, National Nuclear Security Administration Nevada Site Office, 2007. Institutional Control Policies and Implementation for the Area 5 and Area 3 Radioactive Waste Management Sites. DOE/NV/25946--300. Las Vegas, NV. November 2007.

U.S. Environmental Protection Agency, 1999. Cancer Risk Coefficients for Environmental Exposure to Radionuclides. EPA-402-R-99-001, Supplemental CD. Washington, DC. 


\section{Appendix A.1 Waste Volumes and Inventories}

The Area 3 and Area 5 Radioactive Waste Management Sites (RWMSs) future inventories under the No Action and Expanded Operations Alternatives are summarized in Table A1-1. Future waste inventories are assumed to be lognormal distributions with geometric means (GMs) and geometric standard deviations (GSDs) as described below. Future inventories are truncated at maximum model realizations to minimize excessive uncertainty.

Table A1-1.Estimate of the future inventory for the No Action and Expanded Operations Alternatives. Estimates are calculated from 500 LHS realizations and decayed to October 1, 2028, for the Area 5 RWMS and October 1, 2025, for the Area 3 RWMS.

\begin{tabular}{|c|c|c|c|c|c|c|}
\hline \multirow{3}{*}{ Nuclide } & \multirow{2}{*}{\multicolumn{2}{|c|}{$\begin{array}{c}\text { No Action } \\
\text { Area } 5 \text { RWMS SLB }\end{array}$}} & \multicolumn{4}{|c|}{ Expanded Operations } \\
\hline & & & \multicolumn{2}{|c|}{ Area 5 RWMS SLB } & \multicolumn{2}{|c|}{ Area 3 RWMS U-3ah/at } \\
\hline & $\mathrm{GM}(\mathrm{Bq})$ & GSD & $\mathrm{GM}(\mathrm{Bq})$ & GSD & $\mathrm{GM}(\mathrm{Bq})$ & GSD \\
\hline $\mathrm{H}-3$ & $1.4 \mathrm{E}+17$ & 2.45 & $4.4 \mathrm{E}+17$ & 2.45 & $7.1 \mathrm{E}+14$ & 4.19 \\
\hline C-14 & $5.0 \mathrm{E}+12$ & 4.77 & $1.6 \mathrm{E}+13$ & 4.77 & $1.1 \mathrm{E}+10$ & 2.12 \\
\hline $\mathrm{Cl}-36$ & $5.7 E+06$ & 8.99 & $1.8 \mathrm{E}+07$ & 8.99 & $1.6 \mathrm{E}+06$ & 29.65 \\
\hline Ar-42 & $2.7 \mathrm{E}+05$ & $3.4 \mathrm{E}+03$ & $5.0 \mathrm{E}+05$ & $6.0 \mathrm{E}+03$ & $1.4 \mathrm{E}+07$ & 39.54 \\
\hline $\mathrm{K}-40$ & $1.4 \mathrm{E}+10$ & 2.21 & $4.5 E+10$ & 2.21 & $9.6 \mathrm{E}+08$ & 13.22 \\
\hline $\mathrm{Ca}-41$ & $9.4 \mathrm{E}+04$ & $5.9 \mathrm{E}+02$ & $1.9 \mathrm{E}+05$ & $1.0 \mathrm{E}+03$ & Negligible & \\
\hline $\mathrm{Ti}-44$ & $2.7 \mathrm{E}+08$ & $7.4 \mathrm{E}+02$ & $7.2 \mathrm{E}+08$ & $1.1 \mathrm{E}+03$ & $2.3 \mathrm{E}+08$ & $1.1 \mathrm{E}+02$ \\
\hline Co-60 & $5.8 \mathrm{E}+14$ & 4.64 & $1.8 \mathrm{E}+15$ & 4.64 & $5.1 \mathrm{E}+09$ & 2.27 \\
\hline $\mathrm{Ni}-59$ & $1.0 \mathrm{E}+12$ & 3.46 & $3.3 E+12$ & 3.46 & $9.3 \mathrm{E}+07$ & $1.7 \mathrm{E}+02$ \\
\hline $\mathrm{Ni}-63$ & $9.6 \mathrm{E}+13$ & 3.77 & $3.0 \mathrm{E}+14$ & 3.77 & $4.5 \mathrm{E}+10$ & 2.75 \\
\hline Se-79 & $4.2 \mathrm{E}+11$ & $1.2 \mathrm{E}+02$ & $1.3 \mathrm{E}+12$ & $1.3 \mathrm{E}+02$ & $5.2 \mathrm{E}+05$ & $1.0 \mathrm{E}+02$ \\
\hline Kr-85 & $5.6 \mathrm{E}+09$ & 3.62 & $1.8 \mathrm{E}+10$ & 3.62 & $5.6 \mathrm{E}+07$ & $2.7 \mathrm{E}+02$ \\
\hline Sr-90 & $6.4 \mathrm{E}+15$ & 6.86 & $2.0 \mathrm{E}+16$ & 6.86 & $1.1 \mathrm{E}+13$ & 12.82 \\
\hline Zr-93 & $1.4 \mathrm{E}+07$ & 11.21 & $4.4 \mathrm{E}+07$ & 11.21 & Negligible & \\
\hline Nb-93m & $2.0 \mathrm{E}+07$ & 4.63 & $6.3 E+07$ & 4.63 & Negligible & \\
\hline $\mathrm{Nb}-94$ & $1.9 \mathrm{E}+10$ & 26.41 & $6.1 \mathrm{E}+10$ & 26.41 & $4.4 \mathrm{E}+03$ & 94.67 \\
\hline Tc-99 & $1.8 \mathrm{E}+14$ & 3.08 & $5.7 \mathrm{E}+14$ & 3.08 & $1.7 \mathrm{E}+11$ & 2.26 \\
\hline $\mathrm{Pd}-107$ & $1.6 \mathrm{E}+05$ & 7.01 & $5.0 \mathrm{E}+05$ & 7.85 & Negligible & \\
\hline $\mathrm{Ag}-108 \mathrm{~m}$ & $1.8 \mathrm{E}+09$ & $3.5 \mathrm{E}+02$ & $5.8 \mathrm{E}+09$ & $3.5 \mathrm{E}+02$ & Negligible & \\
\hline $\mathrm{Cd}-113 \mathrm{~m}$ & $5.3 E+09$ & 45.49 & $1.6 \mathrm{E}+10$ & 48.76 & Negligible & \\
\hline Sn-121m & $1.3 \mathrm{E}+05$ & 53.25 & $3.4 \mathrm{E}+05$ & 81.73 & Negligible & \\
\hline Sn-126 & 7.7E+09 & 20.17 & $2.4 \mathrm{E}+10$ & 21.42 & $7.5 \mathrm{E}+06$ & $3.6 E+02$ \\
\hline $\mathrm{I}-129$ & $5.8 \mathrm{E}+09$ & 3.77 & $1.8 \mathrm{E}+10$ & 3.77 & $4.2 \mathrm{E}+07$ & 5.91 \\
\hline Cs-135 & $3.8 \mathrm{E}+06$ & 34.86 & $1.2 \mathrm{E}+07$ & 38.26 & Negligible & \\
\hline Cs-137 & $4.3 \mathrm{E}+14$ & 4.25 & $1.4 \mathrm{E}+15$ & 4.25 & $2.4 \mathrm{E}+13$ & 2.15 \\
\hline Ba-133 & $1.3 \mathrm{E}+10$ & 4.37 & $4.2 \mathrm{E}+10$ & 4.37 & $3.0 \mathrm{E}+08$ & 61.56 \\
\hline Pm-145 & $3.2 \mathrm{E}+04$ & 41.31 & $9.5 \mathrm{E}+04$ & 47.41 & Negligible & \\
\hline Pm-146 & $3.0 \mathrm{E}+05$ & 12.36 & 8.7E+05 & 15.74 & Negligible & \\
\hline
\end{tabular}




\begin{tabular}{|c|c|c|c|c|c|c|}
\hline \multirow{3}{*}{ Nuclide } & \multirow{2}{*}{\multicolumn{2}{|c|}{$\begin{array}{c}\text { No Action } \\
\text { Area } 5 \text { RWMS SLB }\end{array}$}} & \multicolumn{4}{|c|}{ Expanded Operations } \\
\hline & & & \multicolumn{2}{|c|}{ Area 5 RWMS SLB } & \multicolumn{2}{|c|}{ Area 3 RWMS U-3ah/at } \\
\hline & $\mathrm{GM}(\mathrm{Bq})$ & GSD & $\mathrm{GM}(\mathrm{Bq})$ & GSD & GM (Bq) & GSD \\
\hline Sm-151 & $6.4 \mathrm{E}+09$ & 5.48 & $2.0 E+10$ & 5.48 & $1.0 \mathrm{E}+05$ & 12.51 \\
\hline Eu-152 & $2.2 E+13$ & 11.72 & $6.8 \mathrm{E}+13$ & 11.72 & $3.0 \mathrm{E}+09$ & 14.98 \\
\hline Eu-154 & $6.8 E+13$ & 8.45 & $2.2 E+14$ & 8.45 & $9.6 \mathrm{E}+08$ & 6.17 \\
\hline Gd-148 & $1.1 \mathrm{E}+04$ & 5.94 & $3.3 E+04$ & 7.40 & Negligible & \\
\hline Ho-166m & $6.1 \mathrm{E}+04$ & $3.4 \mathrm{E}+03$ & $1.5 E+05$ & 4.3E+03 & Negligible & \\
\hline Pt-193 & $1.4 \mathrm{E}+06$ & $3.9 \mathrm{E}+04$ & $2.5 \mathrm{E}+06$ & $6.9 \mathrm{E}+04$ & Negligible & \\
\hline $\mathrm{Pb}-210$ & $1.4 \mathrm{E}+11$ & 1.93 & $4.4 \mathrm{E}+11$ & 1.93 & $9.8 \mathrm{E}+09$ & 3.15 \\
\hline Bi-207 & $5.8 \mathrm{E}+06$ & 5.71 & $1.8 \mathrm{E}+07$ & 5.71 & $6.4 \mathrm{E}+03$ & 85.30 \\
\hline $\mathrm{Bi}-210 \mathrm{~m}$ & $9.4 \mathrm{E}+04$ & $1.1 \mathrm{E}+03$ & $1.8 \mathrm{E}+05$ & $1.9 \mathrm{E}+03$ & $1.9 \mathrm{E}+05$ & 55.11 \\
\hline Ra-226 & $2.5 \mathrm{E}+11$ & 2.04 & $8.0 \mathrm{E}+11$ & 2.04 & $2.1 \mathrm{E}+10$ & 3.73 \\
\hline $\mathrm{Ra}-228$ & $7.0 \mathrm{E}+11$ & 2.11 & $2.2 E+12$ & 2.11 & $2.7 \mathrm{E}+09$ & 2.01 \\
\hline Ac-227 & $3.4 \mathrm{E}+10$ & 5.84 & $1.1 \mathrm{E}+11$ & 5.84 & $3.2 \mathrm{E}+08$ & 8.13 \\
\hline Th-228 & $1.5 \mathrm{E}+12$ & 2.12 & $4.8 \mathrm{E}+12$ & 2.12 & $6.9 \mathrm{E}+09$ & 2.03 \\
\hline Th-229 & $1.3 \mathrm{E}+11$ & 4.26 & $4.2 \mathrm{E}+11$ & 4.26 & $1.9 \mathrm{E}+06$ & 8.61 \\
\hline Th-230 & $4.5 \mathrm{E}+11$ & 2.88 & $1.4 \mathrm{E}+12$ & 2.88 & $6.8 \mathrm{E}+09$ & 2.57 \\
\hline Th-232 & $1.0 \mathrm{E}+12$ & 2.24 & $3.2 E+12$ & 2.24 & $3.2 \mathrm{E}+09$ & 1.69 \\
\hline $\mathrm{Pa}-231$ & $5.8 \mathrm{E}+09$ & 1.96 & $1.8 \mathrm{E}+10$ & 1.96 & $1.7 \mathrm{E}+07$ & 2.52 \\
\hline U-232 & $6.9 \mathrm{E}+11$ & 3.67 & $2.2 \mathrm{E}+12$ & 3.67 & $3.2 E+09$ & 6.07 \\
\hline U-233 & $2.7 \mathrm{E}+13$ & 8.42 & $8.4 \mathrm{E}+13$ & 8.42 & $3.2 E+09$ & 8.14 \\
\hline U-234 & $1.0 \mathrm{E}+14$ & 1.70 & $3.2 E+14$ & 1.70 & $6.8 \mathrm{E}+11$ & 1.97 \\
\hline U-235 & $5.8 \mathrm{E}+12$ & 1.55 & $1.8 \mathrm{E}+13$ & 1.55 & $4.2 \mathrm{E}+10$ & 1.70 \\
\hline U-236 & $2.8 \mathrm{E}+12$ & 1.95 & $8.7 E+12$ & 1.95 & $1.7 \mathrm{E}+10$ & 3.62 \\
\hline $\mathrm{U}-238$ & $2.8 \mathrm{E}+14$ & 1.61 & 8.7E+14 & 1.61 & $1.6 \mathrm{E}+12$ & 2.11 \\
\hline $\mathrm{Np}-237$ & $9.2 \mathrm{E}+10$ & 2.27 & $2.9 E+11$ & 2.27 & $5.3 \mathrm{E}+10$ & 8.91 \\
\hline $\mathrm{Pu}-238$ & $7.0 \mathrm{E}+12$ & 1.90 & $2.2 E+13$ & 1.90 & $1.1 \mathrm{E}+11$ & 3.20 \\
\hline Pu-239 & $1.0 \mathrm{E}+13$ & 1.81 & $3.3 E+13$ & 1.81 & $3.7 \mathrm{E}+11$ & 1.94 \\
\hline Pu-240 & 3.7E+12 & 2.43 & $1.2 \mathrm{E}+13$ & 2.43 & $5.7 \mathrm{E}+10$ & 2.04 \\
\hline Pu-241 & $3.9 \mathrm{E}+13$ & 2.76 & $1.2 \mathrm{E}+14$ & 2.76 & $3.8 \mathrm{E}+11$ & 2.28 \\
\hline Pu-242 & $1.8 \mathrm{E}+11$ & 12.01 & $5.6 \mathrm{E}+11$ & 12.01 & $3.8 \mathrm{E}+07$ & 4.42 \\
\hline Pu-244 & $1.1 \mathrm{E}+05$ & 11.25 & $3.4 \mathrm{E}+05$ & 11.25 & Negligible & \\
\hline Am-241 & $4.8 E+12$ & 2.19 & $1.5 E+13$ & 2.19 & $5.6 \mathrm{E}+10$ & 1.76 \\
\hline $\begin{array}{c}\text { Am- } \\
242 \mathrm{~m}\end{array}$ & $8.8 \mathrm{E}+08$ & 3.43 & $2.8 \mathrm{E}+09$ & 3.43 & $3.5 \mathrm{E}+06$ & 50.41 \\
\hline Am-243 & $1.8 \mathrm{E}+10$ & 4.20 & $5.7 \mathrm{E}+10$ & 4.20 & $1.9 \mathrm{E}+08$ & 3.82 \\
\hline $\mathrm{Cm}-243$ & $2.3 \mathrm{E}+09$ & 3.98 & $7.3 \mathrm{E}+09$ & 3.98 & $2.7 \mathrm{E}+06$ & 10.08 \\
\hline $\mathrm{Cm}-244$ & $1.5 \mathrm{E}+12$ & 3.64 & 4.7E+12 & 3.64 & $2.1 \mathrm{E}+09$ & 2.79 \\
\hline $\mathrm{Cm}-245$ & $1.6 \mathrm{E}+11$ & 8.91 & $5.2 E+11$ & 8.91 & $1.0 \mathrm{E}+08$ & 7.88 \\
\hline $\mathrm{Cm}-246$ & $3.2 \mathrm{E}+10$ & 5.59 & $1.0 \mathrm{E}+11$ & 5.59 & $1.5 \mathrm{E}+07$ & 7.24 \\
\hline $\mathrm{Cm}-247$ & $4.5 \mathrm{E}+05$ & 97.28 & $1.4 \mathrm{E}+06$ & 97.28 & $1.4 \mathrm{E}+03$ & $7.2 \mathrm{E}+04$ \\
\hline
\end{tabular}




\begin{tabular}{|c|c|c|c|c|c|c|}
\hline \multirow{3}{*}{ Nuclide } & \multicolumn{2}{|c|}{ No Action } & \multicolumn{4}{c|}{ Expanded Operations } \\
\cline { 2 - 7 } & \multicolumn{2}{|c|}{ Area 5 RWMS SLB } & \multicolumn{2}{c|}{ Area 5 RWMS SLB } & \multicolumn{2}{c|}{ Area 3 RWMS U-3ah/at } \\
\cline { 2 - 7 } & GM (Bq) & GSD & GM (Bq) & GSD & GM (Bq) & GSD \\
\hline Cm-248 & $3.0 \mathrm{E}+09$ & 3.97 & $9.4 \mathrm{E}+09$ & 3.97 & Negligible & \\
\hline Cf-249 & $1.8 \mathrm{E}+08$ & 3.12 & $5.6 \mathrm{E}+08$ & 3.12 & $2.0 \mathrm{E}+02$ & 3.15 \\
\hline Cf-250 & $3.0 \mathrm{E}+04$ & 31.69 & $7.7 \mathrm{E}+04$ & 48.19 & $1.3 \mathrm{E}+02$ & 3.26 \\
\hline Cf-251 & Negligible & & Negligible & & $4.0 \mathrm{E}+05$ & $7.7 \mathrm{E}+02$ \\
\hline Total & $1.5 \mathrm{E}+17$ & & $4.7 \mathrm{E}+17$ & & $7.5 \mathrm{E}+14$ & \\
\hline
\end{tabular}

Negligible: < 37 Becquerel (Bq) 
This Page Intentionally Left Blank 